\title{
Biologically active metabolite(s) from haemolymph of red-headed centipede Scolopendra subspinipes possess broad spectrum antibacterial activity
}

\author{
Salwa Mansur Ali ${ }^{\dagger}$, Naveed Ahmed Khan ${ }^{\dagger} \mathbb{0}$, K. Sagathevan, Ayaz Anwar and Ruqaiyyah Siddiqui ${ }^{*}$
}

\begin{abstract}
The discovery of novel antimicrobials from animal species under pollution is an area untapped. Chinese red-headed centipede is one of the hardiest arthropod species commonly known for its therapeutic value in traditional Chinese medicine. Here we determined the antibacterial activity of haemolymph and tissue extracts of red-headed centipede, Scolopendra subspinipes against a panel of Gram-positive and Gram-negative bacteria. Lysates exhibited potent antibacterial activities against a broad range of bacteria tested. Chemical characterization of biologically active molecules was determined via liquid chromatography mass spectrometric analysis. From crude haemolymph extract, 12 compounds were identified including: (1) L-Homotyrosine, (2) 8-Acetoxy-4-acoren-3-one, (3) N-Undecylbenzenesulfonic acid, (4) 2-Dodecylbenzenesulfonic acid, (5) 3H-1,2-Dithiole-3-thione, (6) Acetylenedicarboxylate, (7) Albuterol, (8) Tetradecylamine, (9) Curcumenol, (10) 3-Butylidene-7-hydroxyphthalide, (11) Oleoyl Ethanolamide and (12) Docosanedioic acid. Antimicrobial activities of the identified compounds were reported against Gram-positive and Gramnegative bacteria, fungi, viruses and parasites, that possibly explain centipede's survival in harsh and polluted environments. Further research in characterization, molecular mechanism of action and in vivo testing of active molecules is needed for the development of novel antibacterials.
\end{abstract}

Keywords: Centipede, Antibacterials, Superbugs

\section{Introduction}

Given the increasing burden of bacterial infections and multiple-drug resistant bacteria, there is an urgent need for the development of novel antimicrobials (Tacconelli et al. 2018). In the USA alone, at least two million people acquire antibiotic-resistant infections resulting in 23,000 deaths annually (CDC 2018). The rate of emergence of resistant strains is much higher than the rate of introduction of new antibiotics in the market (CDC 2018). The development of antimicrobials from natural products is of prime importance (Mérillon and Rivière 2018; Harvey et al. 2015). Notably, the majority of

\footnotetext{
*Correspondence: ruqaiyyahs@sunway.edu.my

†Salwa Mansur Ali and Naveed Ahmed Khan contributed equally to this manuscript

Department of Biological Sciences, School of Science and Technology, Sunway University, 47500 Subang Jaya, Selangor, Malaysia
}

commercially available natural products are derived from bacteria, fungi and plants. Nearly $70 \%$ of antibiotics are derived from soil dwelling bacteria (Smith 2000) such as actinomycin (from Streptomyces antibioticus), erythromycin (from Streptomyces erythraeus), aminoglycosides (from Streptomyces and Micromonospora) etc. Likewise, the first antibiotic penicillin was isolated from fungus Penicillium notatum (Fleming 1929), cephalosporins from Acremonium species (Newton and Abraham 1955) and ascochital, pestalone, indanonaftol A are antibiotics from various fungal species (Bugni and Ireland 2004; Cueto et al. 2001). Similarly, plant and plant products containing sesquiterpenes, triterpenes, flavonoids, procyanidins are shown to possess broad spectrum antibacterial activity against Gram-positive and Gram-negative bacteria (Ahmad et al. 1994). Of note, Kingdom Animalia represents largest diversity with more than 8 million 
species (Census of Marine Life). Classes such as fishes, amphibians, reptiles, birds and mammals comprises a huge diversity of terrestrial, marine and aquatic fauna (Science daily 2011). Unlike plants, their exposure to polluted environments and disease causing agents is greater. Therefore, it is thought that their ability to defend against pathogenic microorganisms is relevant to humans and must be explored. For example, cockroaches thrive in polluted environments suggesting their innate ability to produce anti-infective agents (Lee et al. 2011). Also, invertebrates particularly insects are used to treat various illnesses and are common in traditional medicines (Costa-Neto 2005). Insects such as hairy arachnids, Chinese black mountain ant, honey bee and bee products, scorpions, grass hoppers, silk worms, termites etc. are believed to possess various health benefits and are used in the treatment of wound healing, pain, cough, inflammation, fever, gastrointestinal related disorders, reproductive illnesses, pneumonia, hemorrhage, diarrhea etc. (Feng et al. 2009; Srivastava et al. 2009). However, the scientific basis of their medicinal properties remains incompletely understood. Previously, we showed the presence of potent antibacterial molecules in cockroaches against methicillin resistant Staphylococcus aureus (MRSA) and neuropathogenic Escherichia coli K1 (Lee et al. 2011; Ali et al. 2016). Several molecules were identified containing isoquinoline group, chromene derivatives, thiazine groups, imidazoles, pyrrole-containing analogs, sulfonamides, furanones, and flavanones with known antibacterial properties (Ali et al. 2016). Among other species, forest centipede, Scolopendra subspinipes, (also named as Vietnamese or Chinese Red-headed centipede) is commonly used in folk medicine, for its various health benefits in the treatment of wounds, pain, inflammation, sores and tumors (Lee et al. 2017; Bajpai et al. 2017; Ding et al. 2016; Choi et al. 2008). Mainly, distributed in East Asian countries, they are large with the maximum length of $20 \mathrm{~cm}$ and feeds primarily on insects, arachnids and small vertebrate animals, and encounter pathogens in their natural habitat (Bush et al. 2001). They must have developed mechanisms to counter infections. Hence, we aim to determine antibacterial activity of $S$. subspinipes against a panel of Gram-positive and Gram-negative bacteria and to identify biological molecule(s) using liquid chromatography mass spectrometry.

\section{Materials and methods}

\section{Bacterial cultures}

Eight clinical isolates were tested in this study, among which MRSA (Malaysian Type Culture Collection MTCC 381123), Bacillus cereus (MTCC 131621) and Streptococcus pyogenes (ATCC 49399) were Gram-positive; while, Escherichia coli K1 (MTCC 710859), Pseudomonas aeruginosa (American Type Culture Collection ATCC 10145), Klebsiella pneumonia (ATCC 13883), Salmonella enterica (ATCC 14028) and Serratia marcescens (ATCC 13880) were Gram-negative. All the strains were resistant to two or more antibiotics (Table 1). A 24 h old bacterial broth culture was used for experiments as previously described (Khan et al. 2008).

\section{Organ lysates of centipede}

Wild forest centipedes (S. subspinipes) with approximate length of $18 \mathrm{~cm}$ were collected from forest plantation from their natural habitat and kept in a glass cage individually overnight at $30{ }^{\circ} \mathrm{C}$ with soil organic matter. $70 \%$ ethanol was used to disinfect dissection tools. Centipedes were kept at $4{ }^{\circ} \mathrm{C}$ for $15 \mathrm{~min}$. The insect was immobilized by the dissection pins on the anterior and posterior end of the body in a wax tray. The head and legs were removed, and the haemolymph was collected aseptically in ethylenediamine tetraacetic acid (EDTA) containing vacutainer by inserting the sterile pipette tip at the lateral opening of the removed limb (Fig. 1). Digestive system was exposed by the vertical incision made along the midline of the body and the sample was removed aseptically. After collecting the haemolymph and gut, muscle tissue was exposed, a sample of which was aseptically removed and suspended in small volume of sterile distilled water. Protease inhibitors (serine/cysteine/metalloproteases) were added and the samples were processed at $4{ }^{\circ} \mathrm{C}$ and gut and muscle tissue were subjected to ten cycles of freeze-thawing. Homogenization of the samples were performed aseptically with mortar and pestle, followed by sonication and cold centrifugation at $10,000 \mathrm{~g}$ for $30 \mathrm{~min}$. Next, the lysates were filtered with $0.2 \mu \mathrm{m}$ pore size sterilized filter to avoid contamination and unwanted residual particles, and the protein concentration was determined by Bio-Rad protein assay kit. Lysates were aliquoted and stored at $-20^{\circ} \mathrm{C}$ until further usage.

\section{Antibacterial assay}

Antibacterial assays were carried out to determine bactericidal and bacteriostatic activities of haemolymph and tissue lysates of centipede as reported previously (Khan et al. 2008). A $24 \mathrm{~h}$ old fresh bacterial culture was adjusted to the absorbance of 0.22 at $595 \mathrm{~nm}$ using a spectrophotometer. Approximately $10^{6}$ bacterial cells suspended in $10 \mu \mathrm{L}$ of broth, were incubated with $100 \mu \mathrm{g} / \mathrm{mL}$ concentration of organ lysates or $10 \%$ haemolymph at $37^{\circ} \mathrm{C}$ for $2 \mathrm{~h}$. After incubation, serial dilution of reaction mixture containing bacterial cells was performed followed by plating on nutrient agar plates (Ali et al. 2016; Khan et al. 2008). Bacteria incubated in PBS/broth alone were used as negative control, however, bacteria incubated with $100 \mu \mathrm{g} / \mathrm{mL}$ of gentamicin were used as positive control. 


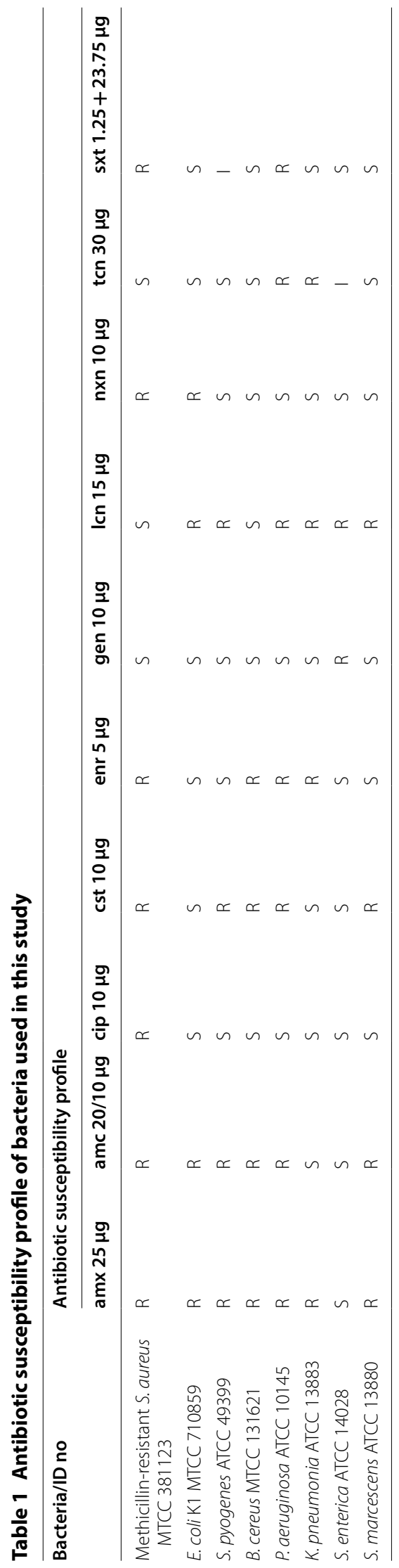




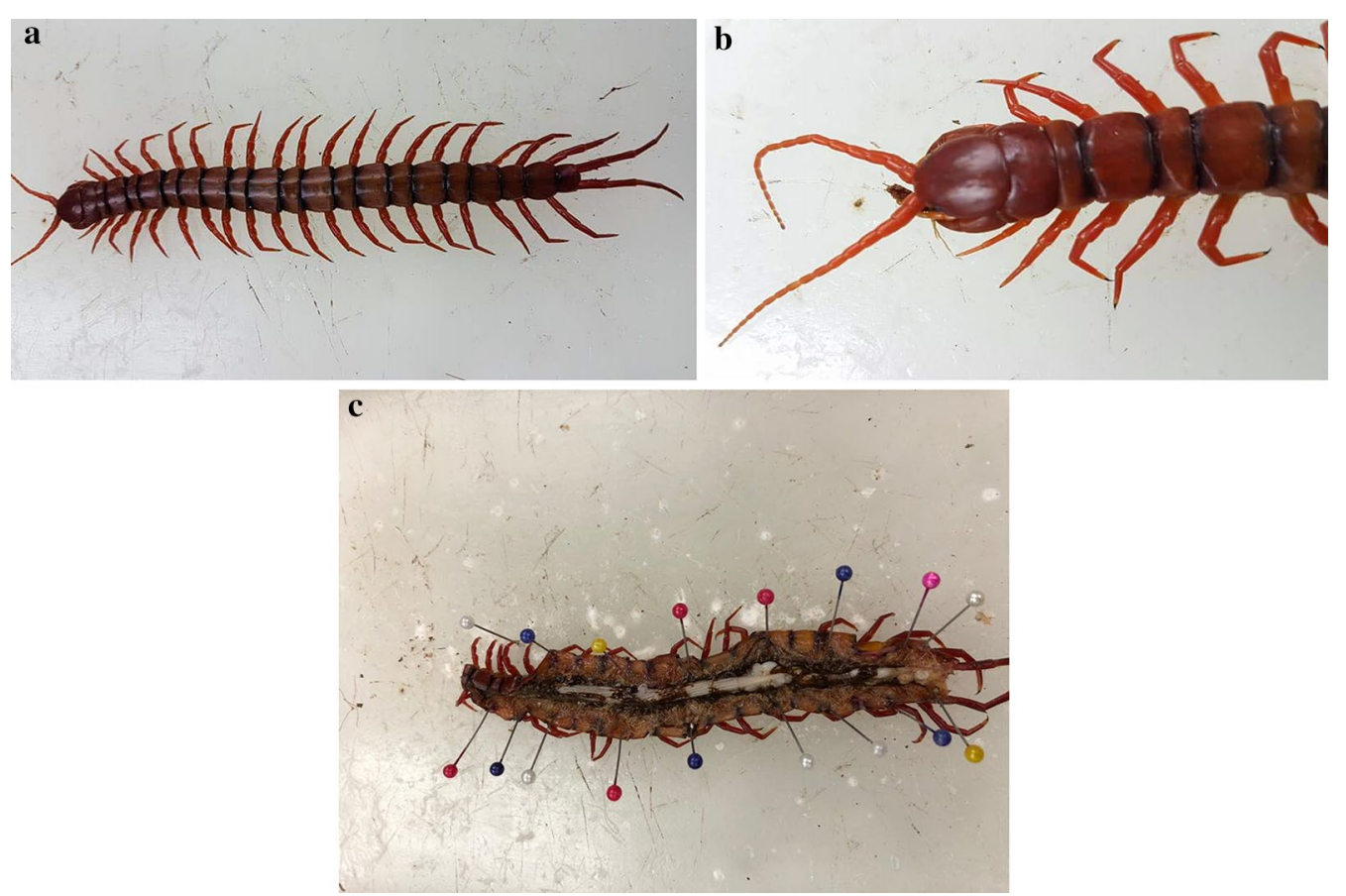

Fig. 1 a Dorsal view of S. subspinipes with intact body segments. b Closer view of upper body of centipede. $\mathbf{c}$ Internal organs of the centipede along the body cavity

Percentage bactericidal/bacteriostatic activity was determined as bacteria surviving relative to the control: $100-(\mathrm{cfu}$ recovered/original inoculum $\times 100)$.

\section{Human keratinocyte cell (HaCaT) cultures}

Human keratinized skin cells (Hacat) (CLS:300493) were purchased from CLS Cell Lines Service, Germany. Cells were cultured in cell culture media comprising RPMI1640, 10\% heat-inactivated fetal bovine serum, $2 \mathrm{mM}$ glutamine, $100 \mathrm{U}$ penicillin $/ \mathrm{mL}, 100 \mu \mathrm{g}$ streptomycin $/ \mathrm{mL}$, non-essential amino acids, and vitamins as previously described (Ali et al. 2016; Khan and Siddiqui 2009). Cell cytotoxicity assays were carried out in 96-well plates by inoculating $5 \times 10^{5} \mathrm{HaCaT}$ cells per well per $\mathrm{mL}$ followed by incubation at $37{ }^{\circ} \mathrm{C}$ with $5 \% \mathrm{CO}_{2}$ for $48 \mathrm{~h}$. Next, complete monolayer formation was observed microscopically prior to cytotoxicity assays.

\section{Bacterial-mediated host cell cytopathogenecity assays}

Centipede haemolymph (10\%) was incubated with $10^{6}$ bacterial cells at $37^{\circ} \mathrm{C}$ for $2 \mathrm{~h}$ followed by co-incubation with approx. $2 \times 10^{6} \mathrm{HaCaT}$ cells at $37{ }^{\circ} \mathrm{C}$ in a $5 \% \mathrm{CO}_{2}$ incubator for $20 \mathrm{~h}$. Next day, cell suspensions containing metabolites and lactate dehydrogenase enzyme (if present) were collected, centrifuged and subjected to reaction with substrate and dye (present in cytotoxicity detection kit) for $10 \mathrm{~min}$ and cytopathogenicity was determined by measuring absorbance of test and control wells at $495 \mathrm{~nm}$. Bacterial-mediated host cell cytopathogenicity were determined and untreated bacteria incubated with human cells were used as controls (Ali et al. 2016; Khan and Siddiqui 2009). Percent cytotoxicity was determined $b y=($ sample value - control value $) /($ total LDH release - control value) $\times 100$.

\section{Liquid chromatography-mass spectrometry (LC-MS): separation and analysis}

Centipede haemolymph was tested for further chemical identity. Haemolymph was subjected for LC-MS analysis on Agilent 1290 infinity liquid chromatograph (Agilent Technologies, Wilmington, DE), coupled with an Agilent 6520 Accurate-Mass quadrupole-time of flight (Q-TOF) mass spectrometer with dual electrospray ionization source (ESI). Reverse-phase high performance liquid chromatography was used for separation of compounds, with an agilent Zorbax Eclipse XDB-C18, Narrow-Bore $2.1 \times 150 \mathrm{~mm}, 3.5$-micron column at $25^{\circ} \mathrm{C}$, and equilibrated with solvent A ( $0.1 \%$ formic acid in Milli-Q water) and solvent B ( $0.1 \%$ formic acid in Acetonitrile). $0.5 \mathrm{~mL} /$ min flow rate with a linear gradient was used as follows: $5 \%$ solvent B for $5 \mathrm{~min}, 100 \%$ solvent B for $20 \mathrm{~min}$, and $100 \%$ solvent $B$ for $25 \mathrm{~min}$. The total run time was $30 \mathrm{~min}$. The compounds were ionized using dual $\mathrm{ESI}+$ Accurate-Mass Q-TOF mass spectrometer. The ion 
source parameters were as follows: capillary voltage at $4000 \mathrm{~V}$ for positive and $3000 \mathrm{~V}$ for negative ion polarity. Flow rate of drying gas was $10 \mathrm{~L} / \mathrm{min}$ with a fragmentor voltage of $125 \mathrm{~V}$ and gas temperature of $300{ }^{\circ} \mathrm{C}$. Pressure of nebulizer gas was set at 45 psi with Quadrupole-TOF detector, while $50 \% \mathrm{MeOH}+50 \%$ Milli-Q water was used as blank after processing each sample.

\section{Identification of compounds through Metlin database}

As described, haemolymph was processed for liquid chromatography mass spectrometric analysis, in order to obtain the spectra of chromatograms determining molecular mass of the compounds in crude extract. The mass spectra of the compounds retrieved from HPLC were run against Metlin_AM_PCDL-N-170502.cdb for identification with exact homology through Agilent Mass Hunter software, while keeping in view compensation needed for charges in positive ESI MS as well as electron fragmentations, to ensure searches for the correct parent mass. Novelty determination of the identified compounds was performed on Scifinder software. However, previously reported compounds were subjected to literature search for biological activities.

\section{Results}

\section{Centipede lysates exhibit potent antibacterial activity} against broad range of bacteria

Centipede's haemolymph was aspirated and lysates were prepared and tested against Gram-positive and Gram-negative bacteria for determination of antibacterial effects. In particular, haemolymph was remarkably active against bacterial strains tested with more than $90 \%$ growth inhibitory activities against MRSA and $B$. cereus, but more than $50 \%$ bacteriostatic activity against E. coli K1, K. pneumonia, S. enterica, S. marcescens and S. pyogenes. Muscle lysates exhibited more than $50 \%$ bacteriostatic activity against $S$. enterica, $S$. marcescens, $P$. aeruginosa and S. pyogenes (Fig. 2).

\section{Host cell cytopathogenecity assays}

To determine the toxic effects of haemolymph treated bacteria against primary human keratinocytes, cytopathogenicity assays were performed. Treated and untreated bacterial cells were incubated at $37{ }^{\circ} \mathrm{C}$ for $2 \mathrm{~h}$, followed by co-incubation with $\mathrm{HaCaT}$ monolayers at $37{ }^{\circ} \mathrm{C}$ in a $5 \% \mathrm{CO}_{2}$ incubator for $20 \mathrm{~h}$ and lactate dehydrogenase enzyme release (cell lysis marker), was measured using a cytotoxicity detection kit. When treated with $10 \%$ haemolymph, B. cereus showed host cell death significantly reduced, from $100 \%$ to only $36 \%(\mathrm{P}<0.05)$. Similarly, E. coli $\mathrm{K} 1$ treated with haemolymph also showed significant reduction in producing host cell damage $(\mathrm{P}<0.05)$. Notably, haemolymph alone produced approximately $25 \%$ host cell damage (data not shown). Overall, the treatment of bacterial cells with centipede's haemolymph reduced bacterial-mediated host cell damage as compared to untreated bacteria (Fig. 3).

\section{Identification of biologically active molecule(s) in centipede haemolymph using liquid chromatography- mass spectrometry}

Centipede haemolymph was subjected to LC-MS (Agilent Technologies 6520 Accurate-Mass Q-TOF mass spectrometer with dual ESI source) for qualitative analyses. Figure 4 shows spectra from negative and positive ion polarity. Compounds present in haemolymph were separated in the column on the basis of mass to charge ratio $(\mathrm{m} / \mathrm{z})$ and retention time. The data obtained from the LC-MS for haemolymph contained 48 compounds in total, out of which identity of 12 compounds was confirmed. These include, (1) L-Homotyrosine, (2) 8-Acetoxy-4-acoren-3-one, (3) N-Undecylbenzenesulfonic

\footnotetext{
(See figure on next page.)

Fig. 2 The crude extracts of red centipede's haemolymph, gut and muscles were prepared and tested in antibacterial bioassays. For negative control, bacteria incubated with nutrient broth/PBS was used and for positive control bacteria incubated with $100 \mu \mathrm{g} / \mathrm{mL}$ of gentamicin was used. Asterisk represents $\mathrm{P}<0.05$. P values were obtained using two-sample T test and two-tailed distribution. a Represents $0 \%$ growth indicating potent bacteriostatic activity of $10 \%$ haemolymph, $100 \mu \mathrm{g} / \mathrm{mL}$ of muscle and gut extracts of red centipede against MRSA. b Represents cidal assay, indicating 50\%, 80\% and 68\% viability of respective extracts against MRSA. c Represents more than $90 \%$ bacteriostatic activity of all the three extracts against B. cereus. d Also represents more than $90 \%$ bactericidal activity for all three extracts against B. cereus. e Represents $49 \%$, $31 \%$ and $63 \%$ growth in bacteriostatic assays respectively against K. pneumoniae. f Represents 48\%, 53\% and 75\% viability in bactericidal assays respectively against K. pneumoniae. g Represents 22\%, 10\% and 49\% growth in bacteriostatic assays respectively against S. enterica. h Represents 55\% and 78\% viability for haemolymh and gut extracts however, muscle extracts was not active in bactericidal assays against S. enterica. i Represents $27 \%, 31 \%$ and $70 \%$ growth in bacteriostatic assays respectively against E. coli K1. j Represents 49\%, 44\% and $73 \%$ viability in bactericidal assays respectively against E. coli K1. k Represents nearly $50 \%$ bacteriostatic activity of all three extracts against S. marcescens. I Represents no bactericidal activity of centipede's extracts against S. marcescens. $\mathbf{m}$ Represents nearly 83,81 and $47 \%$ growth of centipede's haemolymph, gut and muscles respectively against $P$. aeruginosa. $\mathbf{n}$ Represents no bactericidal activity of centipede's extracts against $P$. aeruginosa. o Represents nearly 33,19 and $38 \%$ growth of centipede's haemolymph, gut and muscles respectively against S. pyogenes. p Represents 63,50 and $51 \%$ viability of the extracts respectively against $S$. pyogenes. The results are representative of several experiments performed in duplicates and expressed as the mean \pm standard error
} 

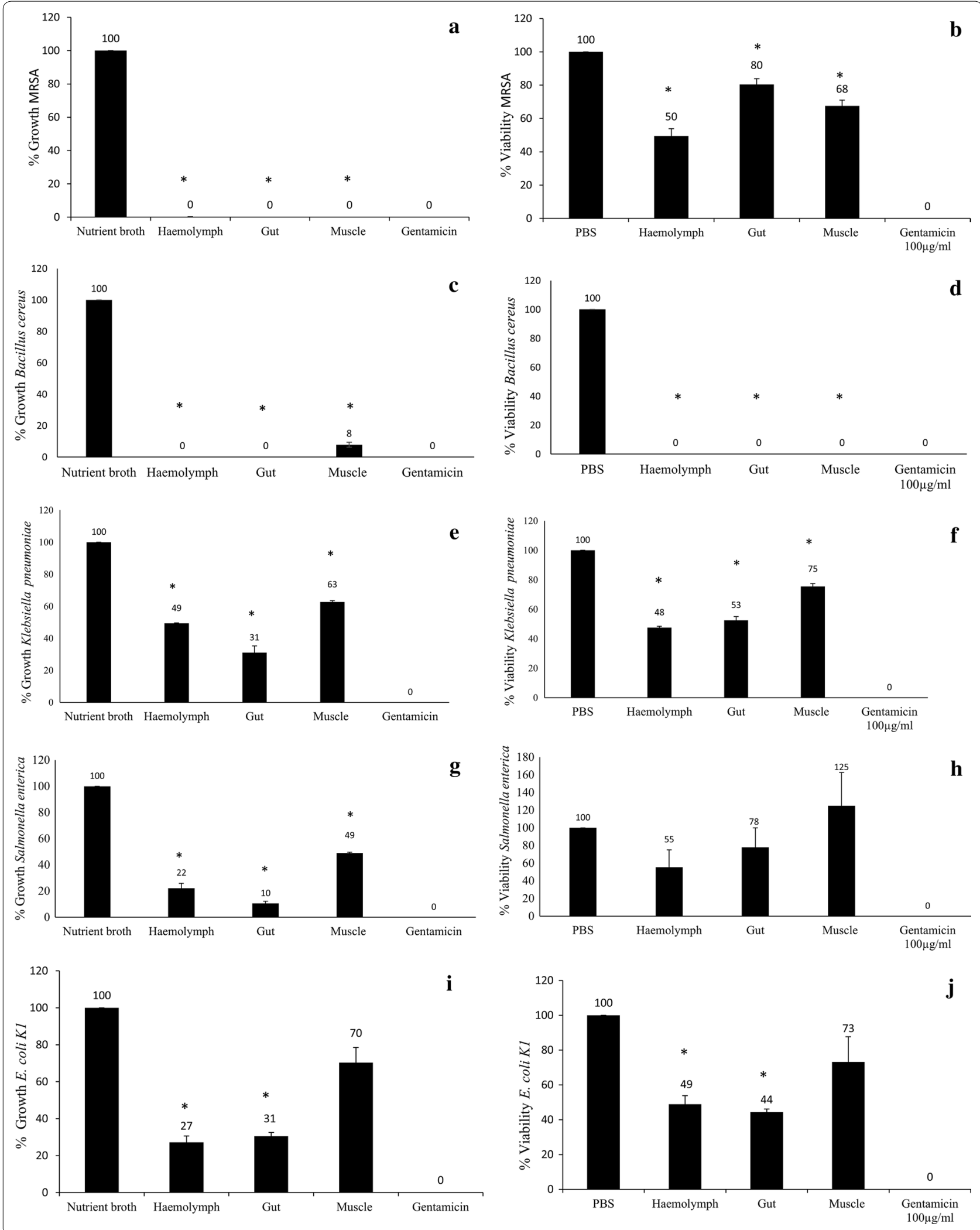

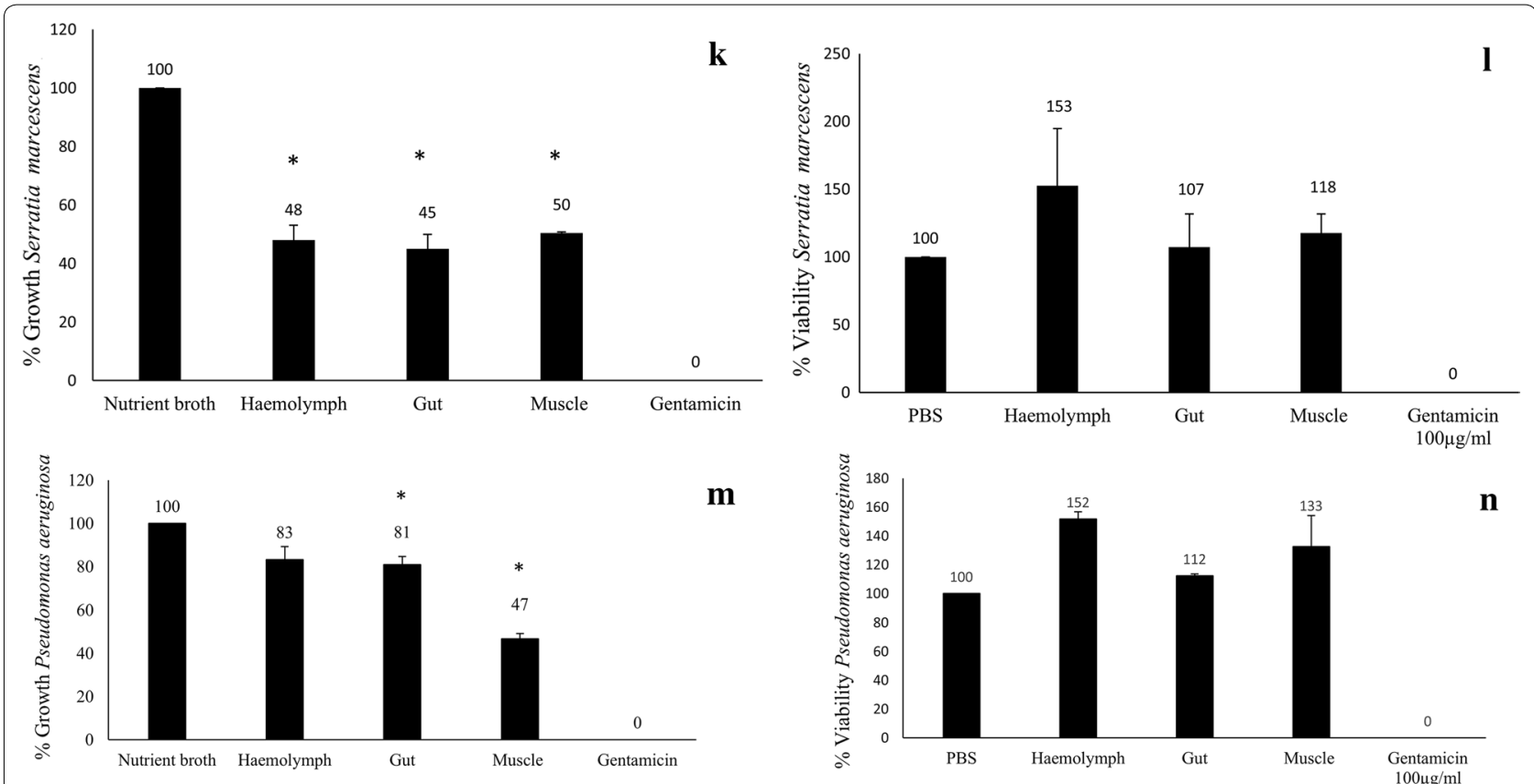

$\mathbf{m}$
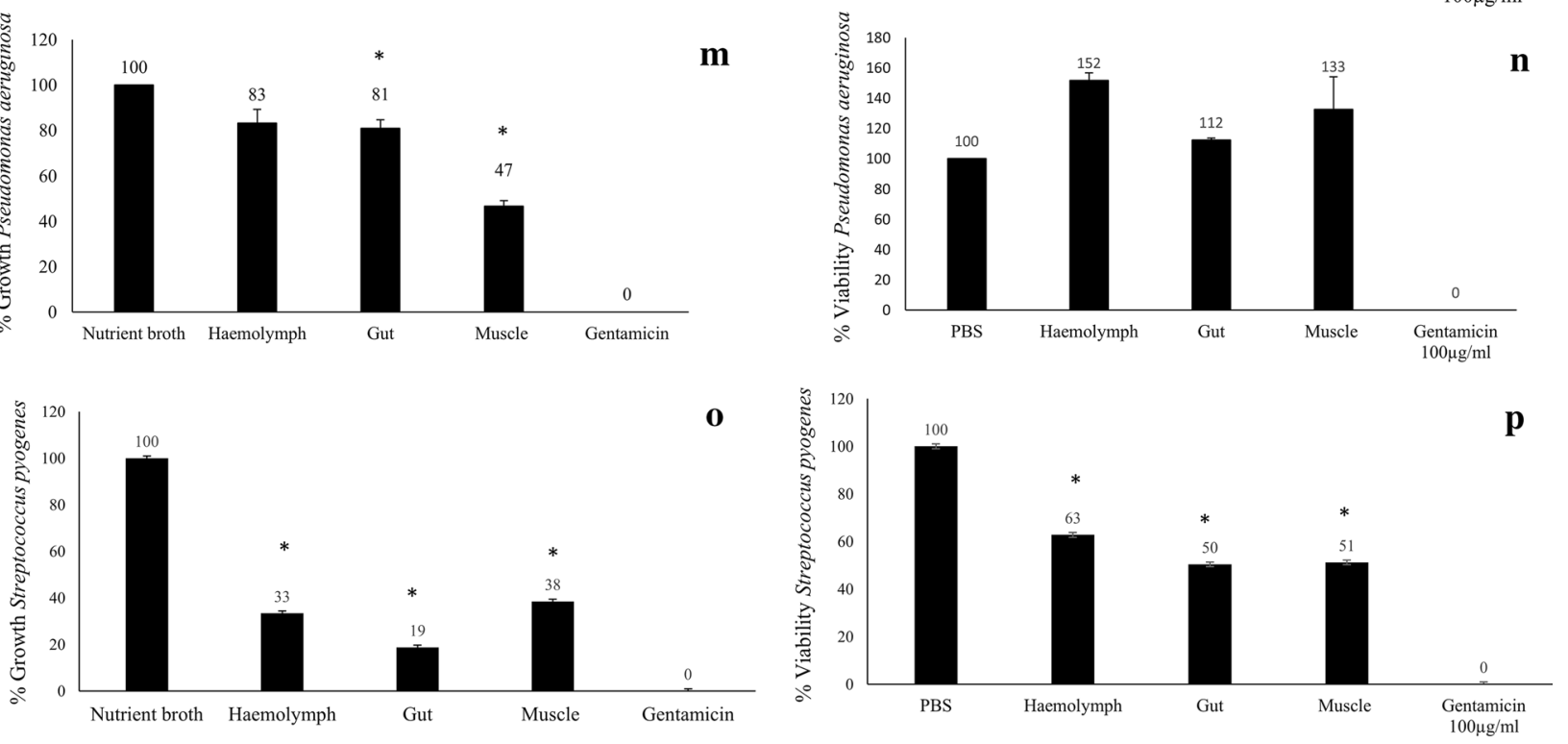

Fig. 2 continued

acid, (4) 2-Dodecylbenzenesulfonic acid, (5) 3H-1,2-Dithiole-3-thione, (6) Acetylenedicarboxylate, (7) Albuterol, (8) Tetradecylamine, (9) Curcumenol, (10) 3-Butylidene7-hydroxyphthalide, (11) Oleoyl Ethanolamide and (12) Docosanedioic acid (Table 2). From remaining 36 compounds, limited information regarding retention time, molecular mass and formula of 23 compounds were determined, whereas for 13 compounds, only molecular mass and retention time were determined (Table 3 ). The 12 compounds identified from centipede haemolymph were subjected for novelty determination via Scifinder software. Interestingly, all of them were found to possess reported biological activities for their exact and homologous structures.

\section{Discussion}

Development of robust antimicrobials from novel sources is the current need to counter drug resistant pathogens (Challinor and Bode 2015; Harvey et al. 2015). Most common sources of antimicrobials are bacteria, fungi, plant and plant products that have been used widely in modern medicine (Abraham et al. 1953; Wagman 1980; Negi et al. 1999). In contrast, discovery of antimicrobials from animal sources is an area explored superficially. This is despite the fact that animals particularly invertebrates such as cockroaches, ants, silk worms, scorpions and tarantulas have been used in traditional medicine for centuries (Costa-Neto 2005). For example, larval therapy is used widely to cure non-healing wounds. This involves, the application of mature blow fly larvae belonging to Sarconesiopsis genus on an open wound, resulting in the secretion of antimicrobial peptides and metabolites (Diaz-Roa et al. 2018). Maggot debridement therapy is effective to cure severe necrotizing fasciitis, caused by more than one type of bacteria such as MRSA, Streptococcus pyogenes, enterococci, E. coli, P. aeruginosa, Clostridium and Bacteroides species (Maya et al. 2014). Maggot debridement therapy is useful in patients suffering from necrotizing fasciitis with an underlying disease who cannot be subjected to surgical procedures such as 


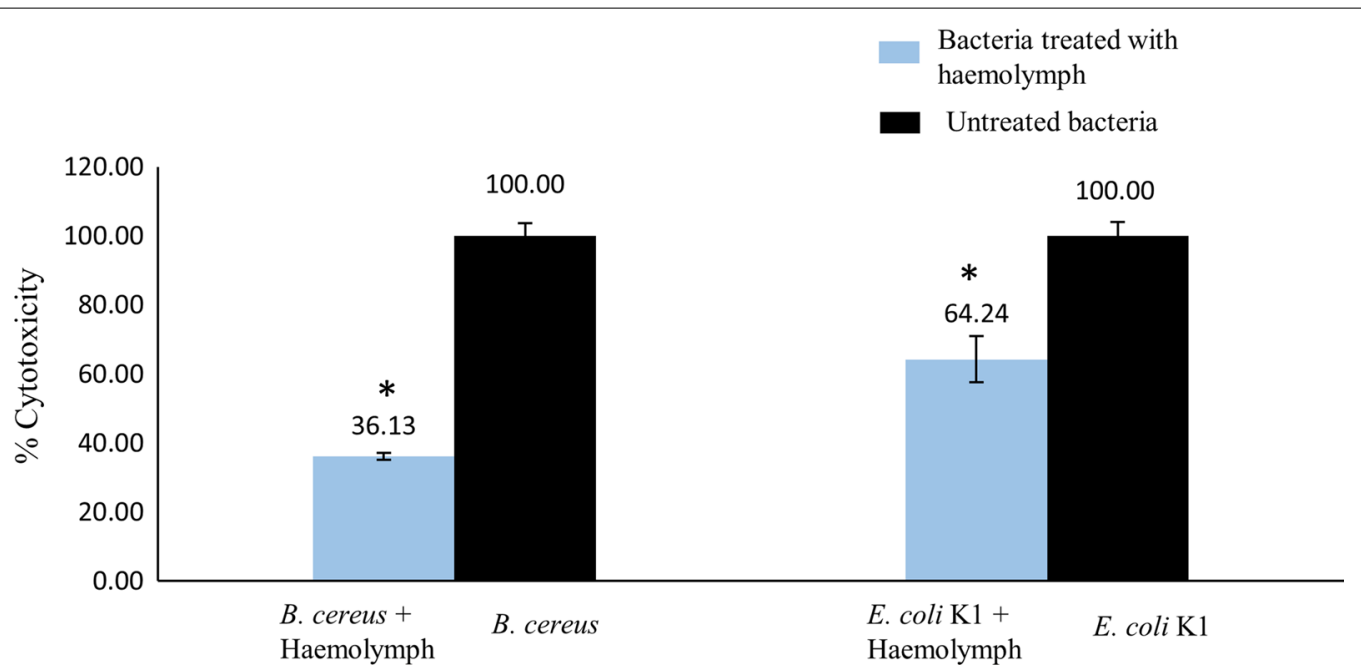

Fig. 3 The haemolymph of red centipede was aspirated and tested in cytopathogenicity assay against Human Keratinocyte HaCaT monolayers. $10 \%$ haemolymph was incubated with $10^{6}$ bacterial cells for $2 \mathrm{~h}$ at $37^{\circ} \mathrm{C}$, followed by the co-incubation with HaCaT monolayers in $5 \% \mathrm{CO}_{2}$ incubator at $37^{\circ} \mathrm{C}$ for $18-20 \mathrm{~h}$. Untreated bacteria incubated with HaCaT monolayers were used as control. Next day, supernatent containg lactate dehygrogenease enzyme were collected, centrifuged and determined by Rosche cytotocicity detection Kit as per guidelines. Significant reduction was observed in the cytopathogenicity caused by the pre-treated bacteria incubated with haemolymph as compared to untreated bacteria. $B$. cereus showed up to $36 \%$ and $E$. coli $\mathrm{K} 1$ showed up to $64 \%$ cytotoxicity to human cells when pre-treated with haemolymph in contrast to untreated bacteria which showed $100 \%$ cytopathogenicity to human cells. The results are representative of several experiments performed in duplicates and expressed as the mean \pm standard error

diabetic patients (Dunn et al. 2002). Other studies showed that application of sterile larvae belonging to genus Lucilia sericata, Protophormia terraenovae, Sarconesiopsis magellanica secretes antimicrobial molecules/peptides such as as $p$-hydroxybenzoic acid, $p$-hydroxyphenylacetic acid, dioxopiperazine proline, seraticin, defensins, cecropins, diptericins and proline-rich peptides with potent anti-biofilm and wound healing properties (Nigam et al. 2010; Chernysh et al. 2018). Similarly, arthropods such as wild centipedes have been used in traditional Chinese medicine, often used to treat various illnesses such as seizures, apoplexy, stroke induced hemiplegia, diphtheria, tuberculosis, pyocutaneous disease etc. (Moon et al. 1996; Undheim and King 2011). In Korea, crushed centipede is used to treat back pains, sores and furuncles (Douglas 2014). Recent studies also highlight its broad range of antimicrobial activity against various pathogens. For example, S. subspinipes mutilans exhibited antifungal activity by membrane permeabilization in Candida albicans (Choi et al. 2013). Similarly, antimicrobial activity of the peptide lacrain, isolated from body extract of $S$. viridicornis showed strong bactericidal activity against Gramnegative bacteria (Chaparro and Da Silva Junior 2016). 3,8-Dihydroxyquinoline also known as jineol, isolated from $S$. subspinipes mutilans showed antibacterial activity by altering the release of potassium ions from food borne pathogenic strains of $E$. coli $\mathrm{O} 157: \mathrm{H} 7$ and S. aureus KCTC-1621 (Bajpai et al. 2017). Several other AMPs such as Scolopendrasin I, V, VII are known to possess broad range of antimicrobial activities against drug resistant pathogens (Wenhua et al. 2006; Peng et al. 2010). For the first time, here we determined the antibacterial activity of the haemolymph/organ lysates of red-headed centipede S. subspinipes, with molecular identification of biological components using LC/MS. Our findings suggest that haemolymph and tissue extract of centipede exhibited antibacterial activity against Gram-positive and Gramnegative bacteria. Haemolymph subjected to chemical characterization indicated the identification of $12 \mathrm{com}$ pounds with reported biological activities against Grampositive and Gram-negative bacteria, fungi, viruses and parasites (Pascal et al. 1985; Komorowska-kulik et al. 1998; Niu et al. 2018; Bierer et al. 1998; Baba et al. 2015). For example, compounds 1, 3, 4, 5, 6, 8, 9 and 12 possess antimicrobial activity against a broad range of microorganisms such as $S$. aureus, $P$. aeruginosa, $P$. mirabilis E. coli, H. pylori, Aspergillus species, Candida species, F. oxysporum, C. neoformans, dermatophyte T. rubrum, A. alternata, C. purpureum, $P$. cactorum, P. infestans, $V$. inaequalis, B. cinerea, E. graminis, P. recondite, Human Papilloma virus, HIV and parasite Giardia.

Moreover, compounds $1,4,5,6,7,9,10,11,12$ possess anticancer activity against colon cancer cells, MCF(breast cancer), NCI-H187 (lung cancer) and KB cells, human gastric cancer cells, HepG2 (Liver carcinoma) cells (Pagano et al. 2017; Wisetsai et al. 2018; Jung et al. 


\section{Fragmentor Voltage $125 \quad$ Collision Energy $0 \quad$ Ionization Mode ESI}

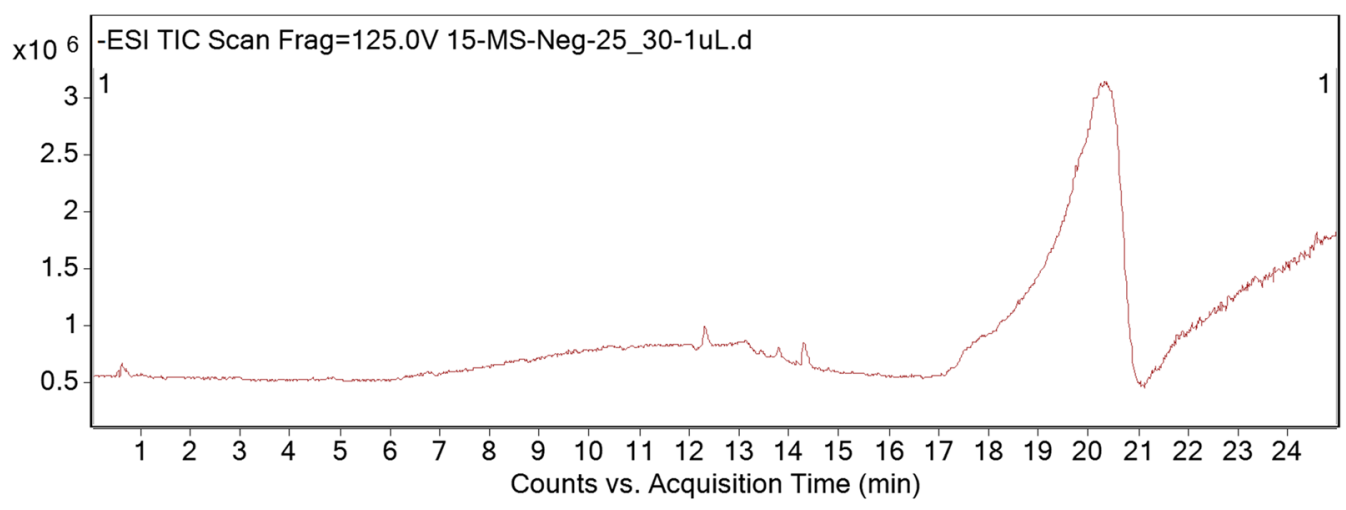

Fragmentor Voltage $125 \quad$ Collision Energy $0 \quad$ Ionization Mode ESI

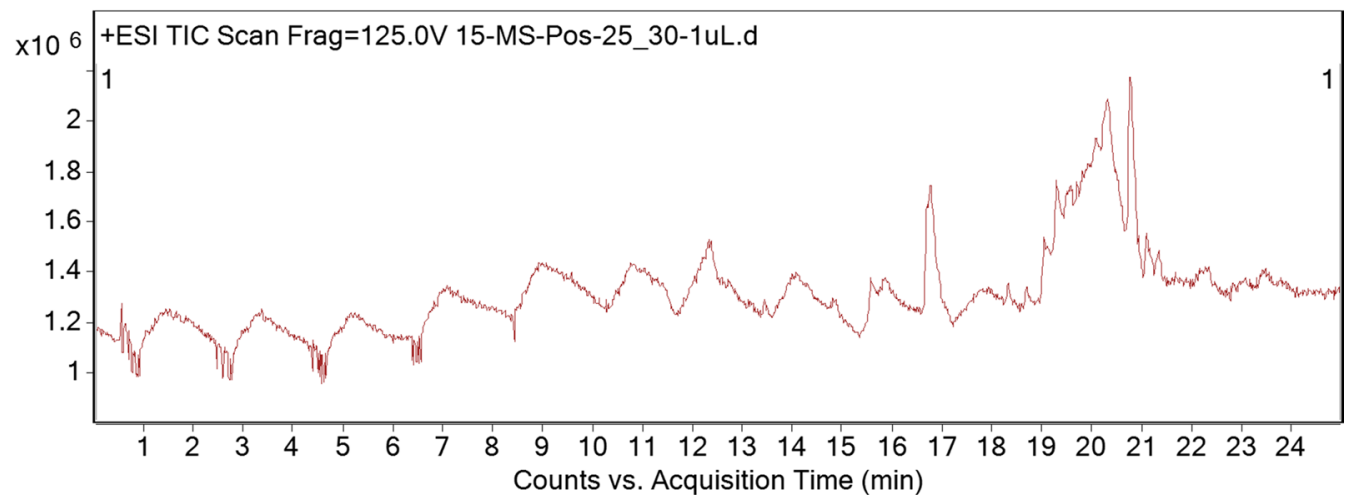

Fig. 4 Scolopendra subspinipes haemolymph was subjected to LC-MS (Agilent 6520 Accurate-Mass Q-TOF mass spectrometer with dual ESI source) for qualitative analyses. The compounds were separated based on $\mathrm{m} / \mathrm{z}$ ratio and retention time in the column. The data obtained from the LC-MS for haemolymph contained numerous peaks, out of which 12 compounds have been detected with full identity and molecular structure, however, 36 compounds were detected with the limited information of only molecular mass and retention time in the column

2018; Ali et al. 2001; Bigge et al. 2003; Kuo et al. 2016; Pelcman and Bengtsson 2018; Lee et al. 2016; Hakonarson et al. 2018) (Table 2).

Interestingly, some of the compounds identified also possess antidiabetic, anti-neurodegenerative, antioxidant, antiepileptic and anticancer activities (Bigge et al. 2003; Wisetsai et al. 2018; Gong et al. 2016). Identified compounds contain furan, tyrosine, thione, albuterol, amines, curcumenol and pthalide moieties, potentially responsible for biological activities. Notably, compounds 2, 5, 9, 10 and 12 are phytochemicals with antibacterial, antifungal, anti-inflammatory, anticancer and analgesic properties (Giannini et al. 2004; Gupta et al. 2018; Tran et al. 2018; Kacem et al. 2016; Brinkworth and Bairlie 1992). Biological significance of these compounds are due to their distinct features and structural arrangement of the functional groups. For example, sulfides and disulfides in cpd 5 are active ingredients. Sulphur has its characteristic property and is an essential component in antibiotics such as sulphonamides (Mitchard 1988). Curcumenol cpd 9, containing tetrahydrofuran is an active five-membered oxygen heterocyclic compound, commonly found in natural products, mainly responsible for their antibacterial activity (Keglevich 2015). Phthalides and fatty acids present in cpd 10 and 12 are also well known for their broad spectrum activities such as antiinflammatory, antimicrobial and anticancer activities (Bierer et al. 1995; Gao et al. 2013; Wisetsai et al. 2018). Notably, 36 compounds were not identified in this study. These are also of potential interest and could represent novel antibacterials (Table 3).

In summary, the discovery of natural antibiotic molecules from animals/invertebrates, exposed to the environmental wastes and pollutants in their natural habitat is a fascinating though unexploited area of research. Hence, it is anticipated that the antibiotics from natural sources are minimal or less toxic for biological system as compared to synthetic antibiotic molecules. Further identification, in vivo testing and clinical trials of potentially 
Table 2 Compounds identified from the red centipede haemolymph

\begin{tabular}{llll}
\hline No. Compound & Formula & Structure \\
\hline 1 L-Homotyrosine $\mathrm{C} 10 \mathrm{H} 13 \mathrm{NO} 3$
\end{tabular}

\section{Reported activity}

Exact structure: epithelial sodium channel blocker activity (Johnson 2015), antibacterial activity against Pseudomonas aeruginosa by inhibiting bacterial 4-hydroxyphenylpyruvate dioxygenase (Pascal et al. 1985), antifungal activity against Candida albicans and Candida glabrata by the inhibition of $\beta$-1,3-glucan synthesis (Klein et al. 2000; Zambias et al. 1992), act as matriptase inhibitors (Maiwald et al. 2016), antitumor activity (Ali et al. 2001), act as coagulation factor Xa inhibitors for treatment of cardiovascular diseases and thromboembolic events (Stürzebecher et al. 2015), antidiabetic activity (Bigge et al. 2003)

Similar structure: antibacterial activity against Staphylococcus aureus (Or 1997), antifungal activity against Candida species (Hammond et al. 1992), antiprotozoal activity against Trypanosoma b. rhodesiense (Mehner et al. 2008), anticancer activity against HT-29 and HCT-116 colorectal cancer cells (Ooi et al. 2010; Mehner et al. 2008), used for the treatment of hyperlipidemia by cholesterol absorption inhibitory activity (Alenfalk et al. 2005), anti-diabetic activity (Bigge et al. 2003), used for the treatment of autoimmune disorders (Surolia et al. 2014)

2 8-Acetoxy-4-

$\mathrm{C} 17 \mathrm{H} 26 \mathrm{O} 3$ acoren-3-one

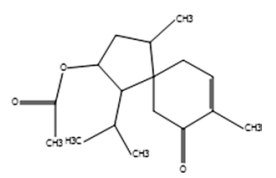

Exact structure: this compound is the component of Acorus calamus (sweet flag) commonly found in spices (hmdb.ca), used for the treatment of epilepsy, amnesia and insomnia (Zhang et al. 2015), anti-germination activity (Nawamaki and Kuroyanagi 1996)

Similar structure: growth inhibitory activity against Staphylococcus aureus, Staphylococcus epidermidis, Bacillus cereus, and Escherichia coli (Chuysinuan et al. 2019), antifungal activity against plant fungal pathogen Pythium myriotylum (Liu et al. 2016), Phytophthora capsici and Pythium myriotylum (Liu et al. 2015), anti-cancer activity against prostate carcinoma and human neuroblastoma cells (Wang et al. 2014), cytotoxic activity against human gastric cancer (BGC-823 cells), cervical cancer (Hela) and human alveolar basal epithelial cells (A549 cells) (Xu et al. 2014), pesticidal activity (Goldblum and Warren 2018)

$3 \quad$ N-Undecylben-

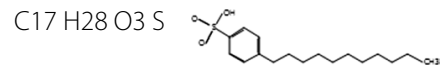

Exact structure: fungicidal activity against Alternaria alternata, Chondrostereum purpureum, Phytophthora cactorum and P. infestans (Komorowskakulik et al. 1998), possess detergent property (Petrov et al. 1958; Matsunaga et al. 1996)

acid

4 2-Dodecylben-

$\mathrm{C} 18 \mathrm{H} 30 \mathrm{O} 3 \mathrm{~S}$

zenesulfonic acid
Similar structure: antibacterial activity against Staphylococcus aureus, Bacillus subtilis, Escherichia coli and Klebsiella pneumonia and antifungal activity against Aspergillus fumigatus (Migahed et al. 2017), anti-tubercular activity against Mycobacterium tuberculosis H37Rv (Tanwar et al. 2016), pesticidal activity (Ichihashi and Okamura 2017; Hatamoto et al. 2016), fungicidal and herbicidal activity (Baba et al. 2014), act as UCH-L1 inhibitor useful for the treatment of cancer, Alzheimer disease and Parkinson disease (Lee et al. 2013), anticancer activity against human colon adenocarcinoma (Caco-2 cell line) (Rojewska et al. 2013), useful for the treatment of cancer and neurodegenerative disease (Lee et al. 2014)

Exact structure: act as agrochemical fungicides against Venturia inaequalis, Botrytis cinerea, Erysiphe graminis, Phytophthora infestans, and Puccinia recondita (Ihori et al. 2018), act as AKT PH domain inhibitors hence useful for the treatment of cancer (Ahad et al. 2011)

Similar structure: antibacterial activity against Staphylococcus aureus, Bacillus subtilis, Escherichia coli and Klebsiella pneumonia and antifungal activity against Aspergillus fumigatus (Migahed et al. 2017), pesticidal activity (Ichihashi and Okamura 2017; Hatamoto et al. 2016), anti-tubercular activity against Mycobacterium tuberculosis H37Rv (Tanwar et al. 2016), act as sitagliptin (anti-diabetic agent) intermediates (Casar and Stavber 2014) 
Table 2 (continued)



\section{Reported activity}

Exact structure: commonly found in brassica (Human Metabolome Database), neuroprotective effects against PC12 (pheochromocytoma of the rat adrenal medulla) cells (Zhang et al. 2018a, b), used for the treatment of ischemic stroke and possess antioxidant and anti-inflammatory activity (Kuo et al. 2017), neurodegenerative activity (Brown et al. 2014), antiviral activity against human papilloma virus (Preston and Murphy 2015), antifungal activity against Candida species (Giannini et al. 2004), act as chemoprotective agent against cancer (Kwak et al. 2001), used for the treatment of autoimmune encephalomyelitis (Kuo et al. 2016)

Similar structure: protective effects against Alzheimer's disease (Wang et al. 2017a, b), antioxidant activity (Koo et al. 2012), used to prevent and treat a disease caused by over activity of a liver X receptor a (LXR a) (Kim et al. 2016), used for the treatment of skin pigmentation disorders (Commo and Michard 2009), neuroprotective activity (Jia et al. 2009), act as cancer preventive agent (Tran et al. 2009), antioxidant activity (Perez-Leal et al. 2017), anti-inflammatory and anti-neurodegenerative activity (Jarrott and Williams 2016)

Exact structure: act as succinate receptor agonists (Geubelle et al. 2017), act as inhibitors of bacterial urease released by Helicobacter pylori and Proteus mirabilis (Macegoniuk et al. 2017), used in the synthesis of quinoline and pyrroloquinoline derivative with anticancer activity against MCF-7 (breast cancer), HepG2 (liver carcinoma) and HCT (human colon cancer) cells (Mohamede et al. 2015), used in the synthesis of anticancer compounds against human gastric carcinoma N87 cells (Zhao et al. 2016), involved in the synthesis of anti-giardia and anti-HIV agent (Al-Masoudi and Abbas 2016), involved in the synthesis of alpha-glucosidase inhibitors (Hyun et al. 2014)

Similar structure: antibacterial activity against Gram-negative bacteria such as Pseudomonas aeruginosa and Escherichia coli (Balkovec et al. 2017), involved in the synthesis of p53 inhibitors as anti-cancer and anti-inflammatory agent (Feder et al. 2015), involved in the preparation of amanita toxins which are effective in abnormal cell growth, proliferative disorder, neuronal disorders, immunological disorders, inflammatory disorders, autoimmune disorders, destructive disorders, bone disorder, infectious disease, neurodegenerative disorder, pancreatitis or kidney disease in a mammal (Zhao et al. 2017)

$7 \quad$ Albuterol

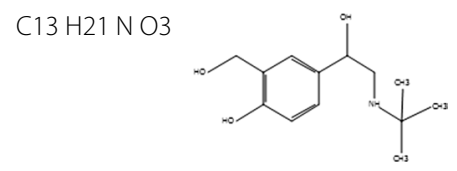

Exact structure: therapeutic agent for lymphedema (Hirata et al. 2018), used in the synthesis of anticancer agent against gastric carcinoma (Zhao et al. 2018), antidepressant activity (Avram et al. 2018), anti-inflammatory and anti-asthmatic effects (Lee et al. 2016; Hakonarson et al. 2018), used to treat cardiovascular diseases (Wang et al. 2018a, b, c), anti-diabetic activity (Pelcman and Bengtsson 2018)

Similar structure: anti-epileptic activity (Stewart et al. 2018), anti-inflammatory and anti-asthmatic effects (Alvarez-Aguilar et al. 2017), used to treat Parkinson's disease (Scherzer 2018), used for the treatment of hypoxemia and dyspnea (Martin 2018), anti-cancer activity (Weinstein et al. 2018), used to treat cardiovascular diseases (Wang et al. 2018a, b, c)

8 Tetradecylamine $\mathrm{C} 14 \mathrm{H} 31 \mathrm{~N}$

Exact structure: bactericidal activity against Staphylococcus aureus and Escherichia coli (Niu et al. 2018; Savage Paul 2017), pesticidal activity (Park et al. 2018), anti-inflammatory activity (Wrasidlo and Natala 2018), antifungal activity against Candida and Aspergillus species by inhibiting ergosterol synthesis (Chandrika, et al. 2018; Garneau-Tsodikova et al. 2018), used as a component in traditional Chinese medicine for the treatment of Coronary heart disease complicated with depression (Zhang et al. 2018a, b)

Similar structure: antibacterial activity against Escherichia coli (Wang et al. 2018a, b, c), anticancer activity against bladder cancer T-24 cells (Wu et al. 2017), involved in the synthesis of antimycobacterial agent (Vosátka et al. 2018); anti-tubercular activity (de Castro et al. 2018), anti-inflammatory activity (Wrasidlo and Natala 2018) 
Table 2 (continued)

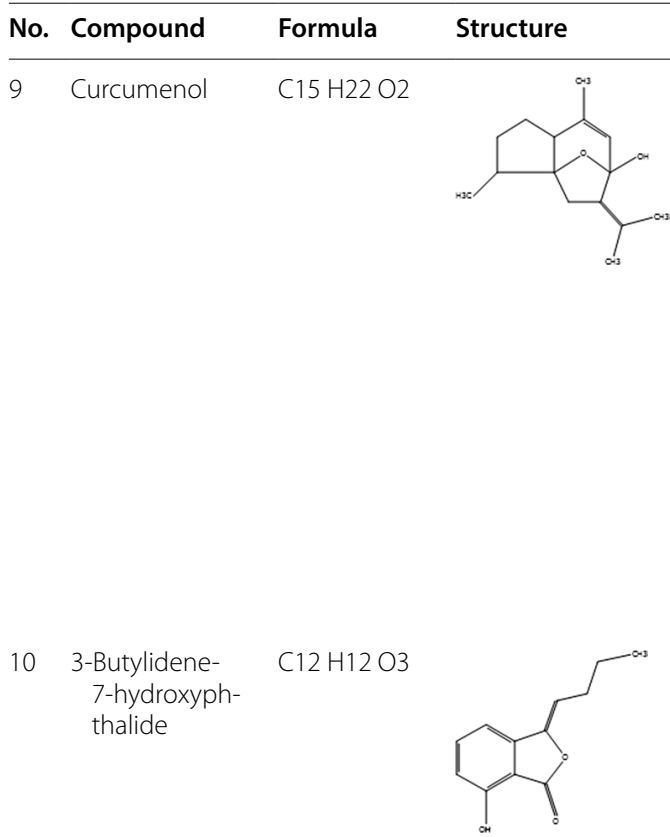

\section{Reported activity}

Exact structure: anti-inflammatory activity (Lee et al. 2019), antistroke agent with anti-inflammatory and cytotoxic activity for sepsis and leukemia, this compound is present in Curcuma longa (Turmeric) (Gupta et al. 2018), anti-proliferative activity against human gastric cancer cells (Jung et al. 2018), antibacterial activity against Proteus mirabilis, Staphylococcus aureus and antifungal activity against Fusarium oxysporum (Kacem et al. 2016)

Similar structure: anti-skin inflammation activity (Lim et al. 2018), neuroprotective activity (Xu et al. 2018), anticancer activity against nasopharyngeal carcinoma cells (Wang et al. 2018a, b), larvicidal activity against Aedes aegypti larvae (Sofian et al. 2017), cytotoxic activity against human prostate carcinoma cells, human skin fibroblasts (HSF) and human melanoma cells (Stojakowska et al. 2019), antileukemic activities against the KG1a and Molt4 cell lines (Anuchapreeda et al. 2018), anti-fungal activity against C. albicans (Li et al. 2017), antioxidant, anti-inflammatory, anticancer, and anti-diabetic activity (Hamidpour et al. 2015), antimicrobial activity against Klebsiella pneumonia, Staphylococcus aureus, Salmonella enterica, Escherichia coli, Pseudomonas aeruginosa, Proteus vulgaris, and fungus Pichia guilliermondii and Candida albicans (Kharkwala et al. 2017)

Exact structure: found in the roots of Angelica sinensis (AS) (Deng et al. 2006), anti-inflammatory activity (Tran et al. 2018), act as synergistic calcium antagonists for the treatment of coronary heart disease (Lei et al. 2018), cytotoxic activity against MCF-7 (breast cancer), NCl-H187 (lung cancer) and KB cells (Wisetsai et al. 2018), act as pancreatic lipase inhibitor for treatment of obesity (Mo et al. 2016), used for the treatment of peptic ulcer (Chung et al. 2005), used for the treatment and prevention of diabetes mellitus (D'orazio et al. 2007)

Similar structure: free radical scavenging activity (Adil et al. 2018), active component of Angelica sinensis (AS) herb, used as the blood-nourishing tonic (Chen et al. 2017), anti-inflammatory activity (Tran et al. 2018), antioxidant and antibacterial activity against Bacillus subtilis, Staphylococcus aureus, Escherichia coli, Pseudomonas aeruginosa, Klebseilla pneumonia, Agrobacterium tumefaciens and antifungal activity against Candida albicans, Mucor sp., Aspergillus flavus, Penicilium expansum (Ksouri et al. 2017), neuroprotective effect on PC12 cells (Lu-Si et al. 2017), used to treat bone diseases (Wang et al. 2017a, b), prevents cancer by increase the oxygen release efficiency of $\mathrm{Hb}$ (Wang and Chen 2017), neuroprotective and anticancer effects against lung (A549), human colon carcinoma (HCT-8), and hepatocarcinoma (HepG2) cancer cell (Gong et al. 2016)

11 Oleoyl ethanola- $\mathrm{C} 20 \mathrm{H} 39 \mathrm{~N} \mathrm{O} 2$ mide

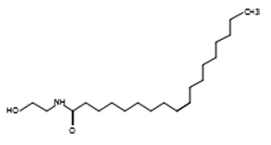

Exact structure: endogenous peroxisome proliferator-activated receptor alpha (PPAR-a) agonist (Gaetani et al. 2003), antitussive activity (Wortley et al. 2017), anti-inflammatory activity (Toguri et al. 2018), used to treat post-traumatic stress disorder by fatty acid amide hydrolase (FAAH) inhibition (Danandeh et al. 2018), useful in the treatment of neurological disorders (Pandey et al. 2018), anti-nausea effect (Rock et al. 2017), analgesic activity (Zubrzycki et al. 2017), anticancer activity against colon cancer cells (Pagano et al. 2017)

Similar structure: anti-inflammatory and pain-relieving effects (Britti et al. 2017), useful in the treatment of inflammatory and neurodegenerative disorders (Barbierato et al. 2018), anticancer activity against colon cancer cell growth (de Cedrón et al. 2018), beneficial in the treatment of HIV-1 associated neurocognitive disorders (HAND) (Hermes et al. 2018), anticancer activity against endometrial cancer (Fonseca et al. 2018), useful in the treatment of intestinal barrier dysfunction (Antón et al. 2018)

12 Docosanedioic $\mathrm{C} 22 \mathrm{H} 42 \mathrm{O} 4$ acid

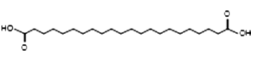

Exact structure: plant metabolite with antifungal activity against Candida albicans, Cryptococcus neoformans, Aspergillus fumigatus and dermatophyte Trichophyton rubrum (Bierer et al. 1995; Bierer et al. 1998), anti-HIV activity (Brinkworth and Bairlie 1992), act as bivalent histamine $\mathrm{H} 2$ receptor (H2R) agonists (Birnkammer et al. 2012), synthesis study (Frost et al. 2010), anti-cancer and anti-inflammatory activity (Gao et al. 2013)

Similar structure: antioxidant activity (Kaneria et al. 2018), skin pigmenting activity (Giuliani et al. 2015), antimalarial activity (Baba et al. 2015), deodorant component (Sato 2016), involved in the treatment of disorders including obesity and diabetes (Just et al. 2016), cosmetic component (Nomura et al. 2016) 
Table 3 Compounds identified in the haemolymph of redheaded centipede

\begin{tabular}{|c|c|c|c|}
\hline $\begin{array}{l}\text { Compound } \\
\text { label }\end{array}$ & Retention time & $\begin{array}{l}\text { Molecular } \\
\text { mass }\end{array}$ & $\begin{array}{l}\text { Molecular } \\
\text { formula }\end{array}$ \\
\hline Cpd 1 & 0.546 & 244.90629 & $\mathrm{C} 3 \mathrm{HCl} 2 \mathrm{~N} 3 \mathrm{O} 4 \mathrm{~S}$ \\
\hline Cpd 2 & 0.595 & 147.97314 & ND \\
\hline Cpd 3 & 14.311 & 267.11138 & $\mathrm{C} 13 \mathrm{H} 17 \mathrm{NO} 5$ \\
\hline Cpd 4 & 18.808 & 340.20795 & $\mathrm{C} 19 \mathrm{H} 32 \mathrm{O} 3 \mathrm{~S}$ \\
\hline Cpd 5 & 19.979 & 117.93689 & ND \\
\hline Cpd 6 & 20.119 & 845.95569 & ND \\
\hline Cpd 7 & 20.256 & 232.95286 & ND \\
\hline Cpd 8 & 20.309 & 135.90438 & ND \\
\hline Cpd 9 & 20.316 & 101.94352 & ND \\
\hline Cpd 10 & 20.329 & 145.93312 & $\mathrm{C} 4 \mathrm{H} 2 \mathrm{~S} 3$ \\
\hline Cpd 11 & 20.393 & 983.99919 & ND \\
\hline Cpd 12 & 20.484 & 230.91116 & ND \\
\hline Cpd 13 & 20.485 & 176.99131 & $\mathrm{C} 4 \mathrm{H} 3 \mathrm{~N} \mathrm{O} 7$ \\
\hline Cpd 14 & 20.486 & 198.9733 & $\mathrm{C} 10 \mathrm{HNO}_{2} \mathrm{~S}$ \\
\hline Cpd 15 & 20.502 & 62.99858 & ND \\
\hline Cpd 16 & 20.533 & 201.86891 & ND \\
\hline Cpd 17 & 20.582 & 227.98881 & $\mathrm{C} 8 \mathrm{H} 4 \mathrm{O} 8$ \\
\hline Cpd 18 & 20.942 & 1034.9965 & ND \\
\hline Cpd 19 & 0.554 & 161.0228 & $\mathrm{C} 7 \mathrm{H} 3 \mathrm{~N} 3 \mathrm{O} 2$ \\
\hline Cpd 20 & 0.586 & 63.00717 & ND \\
\hline Cpd 21 & 0.627 & 161.10154 & $\mathrm{C} 3 \mathrm{H} 11 \mathrm{~N} 7 \mathrm{O}$ \\
\hline Cpd 22 & 0.84 & 203.1128 & C5 H13 N7 O2 \\
\hline Cpd 23 & 12.338 & 227.18775 & $\mathrm{C} 13 \mathrm{H} 25 \mathrm{~N} \mathrm{O} 2$ \\
\hline Cpd 24 & 14.833 & 295.21517 & $\mathrm{C} 17 \mathrm{H} 29 \mathrm{NO} 3$ \\
\hline Cpd 25 & 15.584 & 346.24091 & $\mathrm{C} 16 \mathrm{H} 34 \mathrm{~N} 4 \mathrm{O} 2 \mathrm{~S}$ \\
\hline Cpd 26 & 16.695 & 524.3939 & $\mathrm{C} 28 \mathrm{H} 52 \mathrm{~N} 4 \mathrm{O} 5$ \\
\hline Cpd 27 & 16.72 & 56.06329 & $\mathrm{C} 4 \mathrm{H} 8$ \\
\hline Cpd 28 & 16.752 & 148.01597 & $\mathrm{C} 8 \mathrm{H} 4 \mathrm{O} 3$ \\
\hline Cpd 29 & 16.759 & 480.36669 & $\mathrm{C} 26 \mathrm{H} 48 \mathrm{~N} 4 \mathrm{O} 4$ \\
\hline Cpd 30 & 16.821 & 436.34066 & $\mathrm{C} 23 \mathrm{H} 48 \mathrm{O} 7$ \\
\hline Cpd 31 & 16.875 & 392.31449 & $\mathrm{C} 22 \mathrm{H} 40 \mathrm{~N} 4 \mathrm{O} 2$ \\
\hline Cpd 32 & 18.324 & 386.27256 & $\mathrm{C} 27 \mathrm{H} 34 \mathrm{~N} 2$ \\
\hline Cpd 33 & 20.509 & 610.16105 & $\begin{array}{l}\mathrm{C} 37 \mathrm{H} 27 \mathrm{Cl} \mathrm{N} 4 \\
\mathrm{OS}\end{array}$ \\
\hline Cpd 34 & 21.305 & 701.20692 & $\mathrm{C} 44 \mathrm{H} 32 \mathrm{Cl} \mathrm{N} 3 \mathrm{O} 4$ \\
\hline Cpd 35 & 22.174 & 662.44722 & C33 H58 N8 O6 \\
\hline Cpd 36 & 22.316 & 775.22523 & ND \\
\hline
\end{tabular}

$N D$ not determined

active metabolites can act as a milestone for the synthesis and development of novel drug leads.

\section{Abbreviations}

MRSA: methicillin resistant Staphylococcus aureus; MTCC: Malaysian Type Culture Collection; ATCC: American Type Culture Collection; EDTA: ethylenediamine tetraacetic acid; cfu: colony forming units; Hacat: human keratinized skin cells; RPMI: Roswell Park Memorial Institute; LDH: lactate dehydrogenase;
LC-MS: liquid chromatography-mass spectrometry; Q-TOF: quadrupole-time of flight; ESI: electrospray ionization.

\section{Acknowledgements}

Authors are grateful to N. Akbar for providing technical assistance.

\section{Authors' contributions}

NAK and RS conceived the study. SA and KS sourced the invertebrates and carried out all dissections. SA carried out all experiments under the supervision of RS and NAK. SA carried out LC/MS analyses under the supervision of AA. SA prepared the first draft of the manuscript under the supervision of RS. NAK and RS corrected the manuscript. All authors read and approved the final manuscript.

\section{Funding}

This study was funded by the FRGS and Sunway University, Malaysia.

\section{Availability of data and materials}

All the data analysed in this study are included in this article.

\section{Ethics approval and consent to participate}

This article does not contain any studies with human participants or vertebrates performed by any of the authors.

\section{Consent for publication}

Not applicable.

\section{Competing interests}

The authors declare that they have no competing interests.

Received: 6 May 2019 Accepted: 15 June 2019

Published online: 28 June 2019

\section{References}

Abraham EP, Newton GGF, Crawford K, Burton HS, Hale CW (1953) Cephalosporin $\mathrm{N}$ : a new type of penicillin. Nature 171:343

Adil M, Ren X, Kang DI, Jeong BR (2018) Effect of explant type and plant growth regulators on callus induction, growth and secondary metabolites production in Cnidium officinale Makino. Mol Biol Rep 45:1919-1927

Ahad AM, Zuohe S, Du-Cuny L, Moses SA, Zhou LL, Zhang S, Powis G, Meuillet EJ, Mash EA (2011) Development of sulfonamide AKT PH domain inhibitors. Bioorg Med Chem 19:2046-2054

Ahmad VU, Ahmad WU, Aliya R, Baqai FT, Iabal S, Khatoon R, Mohammad FV, Noorwala M, Perveen S, Pervez A, Saba N (1994) New natural products from terrestrial medicinal plants and marine algae. Pure Appl Chem 66:2311-2314

Alenfalk S, Dahlstroem M, Hunegnaw F, Karlsson S, Lemurell M, Lindqvist AM, Skjaeret T, Starke I (2005) Preparation of diphenylazetidinone amino acid derivatives having cholesterol absorption inhibitory activity. PCT Int Appl WO 2005061452 A1 20050707

Ali S, Tang HY, Mayhew E, Janoff AB (2001) Preparation of ceramide derivatives for pharmaceutical use as antitumor agents. PCT Int Appl WO 2001072701 A1 20011004

Ali SM, Siddiqui R, Ong SK, Shah MR, Anwar A, Heard PJ, Khan NA (2016) Identification and characterization of antibacterial compound (s) of cockroaches (Periplaneta americana). Appl Microbiol Biotechnol 101:253-286

Al-Masoudi NA, Abbas ZA (2016) Synthesis and biological activity of new metronidazole derivatives. Monatsh Chem 147:383-390

Alvarez-Aguilar A, Rosales-Hernández FJ, Francisco J (2017) Quantum analysis of the interaction of Salbutamol and Nt. World J Pharm Pharm Sci 6:62-70

Antón M, Rodríguez-González A, Ballesta A, González N, Del Pozo A, de Fonseca FR, Gómez-Lus ML, Leza JC, García-Bueno B, Caso JR, Orio L (2018) Alcohol binge disrupts the rat intestinal barrier: the partial protective role of oleoylethanolamide. Br J Pharmacol 175:4464-4479

Anuchapreeda S, Khumpirapang N, Rupitiwiriya K, Tho-iam L, Saiai A Okonogi S, Usuki T (2018) Cytotoxicity and inhibition of leukemic cell 
proliferation by sesquiterpenes from rhizomes of Mah-Lueang (Curcuma cf. viridiflora Roxb.). Bioorg Med Chem Lett 28:410-414

Avram S, Milac AL, Mernea M, Alexandrescu IM, Borcan LC, Borcan F (2018) Predicted mechanism of antiasthmatic drugs in depression based on their interaction with SERT and 5-HT1A receptors. Curr Enzyme Inhib 14:51-60

Baba K, Kuroki N, Kobayashi M, Hakuno F (2014) Pyrazinecarboxamide derivative or salt comprising agricultural and horticultural fungicide compositions and methods of use thereof. Jpn Kokai Tokkyo Koho JP 2014224067 A 20141204

Baba MS, Zin NM, Hassan ZAA, Latip J, Pethick F, Hunter IS, Edrada-Ebel R, Herron PR (2015) In vivo antimalarial activity of the endophytic actinobacteria, Streptomyces SUK 10. J Microbiol 53:847-855

Bajpai VK, Shukla S, Paek WK, Lim J, Kumar P, Na M (2017) Antibacterial action of jineol isolated from Scolopendra subspinipes mutilans against selected foodborne pathogens. Front Microbiol 8:552

Balkovec JM, Bensen DC, Blizzard T, Borchardt Allen, Brady TP, Chen ZY, Do QT, Jiang W, Lam T, Locke JB, Noncovich A (2017) Compositions and methods for the treatment of bacterial infections. PCT Int Appl WO 2017218922 A2 20171221

Barbierato M, Skaper SD, Facci L (2018) Oligodendrocyte progenitor cell cultures: a model to screen neurotrophic compounds for myelin repair. Neurotrophic factors. Humana Press, New York, pp 155-166

Bierer DE, Gerber RE, Jolad SD, Ubillas RP, Randle J, Nauka E, Latour J, Dener $J M$, Fort DM (1995) Isolation, structure elucidation, and synthesis of irlbacholine, 1, 22-Bis [[[2-(trimethylammonium) ethoxy] phosphinyl] oxy] docosane: a novel antifungal plant metabolite from Irlbachia alata and Anthocleista djalonensis. J Org Chem 60:7022-7026

Bierer DE, Dener JM, Truong TV (1998) Process for the preparation of monoand bis (phosphocholine) derivatives which have antifungal activity. U.S. Patent 5,811,568

Bigge CF, Bridges AJ, Casimiro-Garcia A, Fakhoury SA, Lee HT, Reed JE, Schaum RP, Schlosser KM, Sexton KE, Zhou H (2003) Preparation of azoles as oral antidiabetic agents. PCT Int Appl WO 2003018553 A1 20030306

Birnkammer T, Spickenreither A, Brunskole I, Lopuch M, Kagermeier N, Bernhardt G, Dove S, Seifert R, Elz S, Buschauer A (2012) The bivalent ligand approach leads to highly potent and selective acylguanidinetype histamine $\mathrm{H} 2$ receptor agonists. J Med Chem 55:1147-1160

Brinkworth RI, Bairlie DP (1992) Non-peptidic anti-AIDS agents: inhibition of HIV-1 proteinase by disulfonates. Biochem Biophys Res Commun 188:624-630

Britti D, Crupi R, Impellizzeri D, Gugliandolo E, Fusco R, Schievano C, Morittu VM, Evangelista M, Di Paola R, Cuzzocrea S (2017) A novel composite formulation of palmitoylethanolamide and quercetin decreases inflammation and relieves pain in inflammatory and osteoarthritic pain models. BMC Vet Res 13:229

Brown DA, Betharia S, Yen JH, Tran Q, Mistry H, Smith K (2014) Synthesis and structure-activity relationships study of dithiolethiones as inducers of glutathione in the SH-SY5Y neuroblastoma cell line. Bioorg Med Chem Lett 24:5829-5831

Bugni TS, Ireland CM (2004) Marine-derived fungi: a chemically and biologically diverse group of microorganisms. Nat Prod Rep 21:143-163

Bush SP, King BO, Norris RL, Stockwell SA (2001) Centipede envenomation. Wilderness Environ Med 12:93-99

Casar Z, Stavber G (2014) Preparation of sitagliptin intermediates U.S. Pat Appl Publ US 20140187558 A1 20140703

Centers for Disease Control and Prevention (2018) Antibiotic/Antimicrobial resistance. https://www.cdc.gov/drugresistance/about.html. Accessed 11 June 2019

Challinor VL, Bode HB (2015) Bioactive natural products from novel microbial sources. Ann N Y Acad Sci 1354:82-97

Chandrika NT, Shrestha SK, Ngo HX, Howard KC, Garneau-Tsodikova S (2018) Novel fluconazole derivatives with promising antifungal activity. Bioorg Med Chem 26:573-580

Chaparro E, Da Silva Junior PI (2016) Lacrain: the first antimicrobial peptide from the body extract of the Brazilian centipede Scolopendra viridicornis. Int J Antimicrob Agents 48:277-285

Chen WR, Yu Y, Zulfajri M, Lin PC, Wang CC (2017) Phthalide derivatives from Angelica Sinensis decrease hemoglobin oxygen affinity: a new allosteric-modulating mechanism and potential use as 2,3-BPG functional substitutes. Sci Rep 7:5504

Chernysh S, Gordya N, Tulin D, Yakovlev A (2018) Biofilm infections between Scylla and Charybdis: interplay of host antimicrobial peptides and antibiotics. Infect Drug Resist 11:501

Choi YK, Lee DD, Kim GW, Koo BS (2008) Antioxidative effects of Scolopendra subspinipes. J Orient Neuropsychiatry 19:129-142

Choi H, Hwang JS, Lee DG (2013) Antifungal effect and pore-forming action of lactoferricin B like peptide derived from centipede Scolopendra subspinipes mutilans. Biochim Biophys Acta Biomembr 1828:2745-2750

Chung YJ, Kim YC, Lee KH, Namgung MA (2005) Peptic ulcer treating agent inhibiting activity of proton pump to inhibit secretion of gastric acid. Repub Korean Kongkae Taeho Kongbo KR 2005023998 A 20050310

Chuysinuan P, Chimnoi N, Reuk-Ngam N, Khlaychan P, Makarasen A, Wetprasit N, Dechtrirat D, Supaphol P, Techasakul S (2019) Development of gelatin hydrogel pads incorporated with Eupatorium adenophorum essential oil as antibacterial wound dressing. Polym Bull 76:701-724

Commo S, Michard Q (2009) Use of dithiolethione derivatives for the treatment of skin pigmentation disorders. Fr Demande FR 2925336 A1 20090626

Costa-Neto EM (2005) Entomotherapy, or the medicinal use of insects. J Ethnobiol 25:93-115

Cueto M, Jensen PR, Kauffman C, Fenical W, Lobkovsky E, Clardy J (2001) Pestalone, a new antibiotic produced by a marine fungus in response to bacterial challenge. J Nat Prod 64:1444-1446

Danandeh A, Vozella V, Lim J, Oveisi F, Ramirez GL, Mears D, Wynn G, Piomelli D (2018) Effects of fatty acid amide hydrolase inhibitor URB597 in a rat model of trauma-induced long-term anxiety. Psychopharmacology 235:3211-3221

De Castro PP, Campos DL, Pavan FR, Amarante GW (2018) Dual-protected amino acid derivatives as new antitubercular agents. Chem Biol Drug Des 92:1576-1580

De Cedrón MG, Vargas T, Madrona A, Jiménez A, Pérez-Pérez MJ, Quintela JC, Reglero G, San-Félix A, De Molina AR (2018) Novel polyphenols that inhibit colon cancer cell growth affecting cancer cell metabolism. J Pharmacol Exp Ther 366:377-389

Deng S, Chen SN, Yao P, Nikolic D, van Breemen RB, Bolton JL, Fong HH, Farnsworth NR, Pauli GF (2006) Serotonergic activity-guided phytochemical investigation of the roots of Angelica s inensis. J Nat Prod 69:536-541

Diaz-Roa A, Patarroyo MA, Bello FJ, Da Silva Jr PI (2018) Sarconesin: Sarconesiopsis magellanica blowfly larval excretions and secretions with antibacterial properties. Front Microbiol 9:2249

Ding D, Guo YR, Wu RL, Qi WY, Xu HM (2016) Two new isoquinoline alkaloids from Scolopendra subspinipes mutilans induce cell cycle arrest and apoptosis in human glioma cancer U87 cells. Fitoterapia 110:103-109

D'orazio D, De Saizieu A, Schueler G, Raederstorff D, Teixeira S, Schmidt YW, Weber P, Wolfram S (2007) Use of phthalide derivatives for the treatment and prevention of diabetes mellitus. US Patent Application $10 / 556,199$

Douglas B (2014) Science, voyages, and encounters in oceania, 1511-1850. Springer, Berlin

Dunn C, Raghavan U, Pfleiderer AG (2002) The use of maggots in head and neck necrotizing fasciitis. J Laryngol Otol 116:70-72

Feder M, Kalinowska I, Jaszczewska JA, Burchard E, Lewandowski W, Bulkowska U, Mazur M, Wos K (2015) Preparation of 1,1',2,5'-tetrahydrospiro[indole$3,2^{\prime}$-pyrrole]-2,5'-dione derivatives useful as inhibitors of p53Mdm2 protein-protein interactions. PCT Int Appl WO 2015189799 A1 20151217

Feng Y, Zhao M, He Z, Chen Z, Sun L (2009) Research and utilization of medicinal insects in China. Entomol Res 39:313-316

Fleming A (1929) On the antibacterial action of cultures of a Penicillium, with special reference to their use in the isolation of B. influenzae. Br J Exp Pathol 10:226

Fonseca BM, Correia-da-Silva G, Teixeira NA (2018) Cannabinoid-induced cell death in endometrial cancer cells: involvement of TRPV1 receptors in apoptosis. J Physiol Biochem 74:261-272

Frost JW, Millis J, Tang Z (2010) Methods for producing dodecanedioic acid and derivatives thereof. PCT Int Appl WO 2010085712 A2 20100729

Gaetani S, Oveisi F, Piomelli D (2003) Modulation of meal pattern in the rat by the anorexic lipid mediator oleoylethanolamide. Neuropsychopharmacology 28:1311 
Gao Y, Vlahakis JZ, Szarek WA, Brockhausen I (2013) Selective inhibition of glycosyltransferases by bivalent imidazolium salts. Bioorg Med Chem 21:1305-1311

Garneau-Tsodikova S, Shrestha SK, Garzan A, Chandrika NT (2018) Preparation of 1,2,4-triazole derivatives as antifungal agents. U.S. Pat Appl Publ US 20180194742 A1 20180712

Geubelle P, Gilissen J, Dilly S, Poma L, Dupuis N, Laschet C, Abboud D, Inoue A, Jouret F, Pirotte B, Hanson J (2017) Identification and pharmacological characterization of succinate receptor agonists. Br J Pharmacol 174:796-808

Giannini FA, Aimar ML, Sortino M, Gomez R, Sturniollo A, Juarez A, Zacchino S, de Rossi RH, Enriz RD (2004) In vitro-in vivo antifungal evaluation and structure-activity relationships of $3 \mathrm{H}-1$, 2-dithiole-3-thione derivatives. Farmaco 59:245-254

Giuliani G, Paus R, Ramot Y, Becker A, Baroni S, Giuliani SA (2015) Compounds with a skin pigmenting activity and pharmaceutical or cosmetic compositions containing them. U.S. Patent 9,192,595

Goldblum S, Warren CB (2018) Solavetivone and 5-epi-beta-vetivone as pest repellants and pesticides. U.S. Patent Application 15/837,830

Gong W, Zhou Y, Li X, Gao X, Tian J, Qin X, Du G (2016) Neuroprotective and cytotoxic phthalides from Angelicae Sinensis Radix. Molecules 21:549

Gupta S, Ahmad H, Shukla B, Ojha N, Dwivedi AK (2018) Isolation, structural characterization, and validation of a new compound present in noncarbonyl Curcuma longa (NCCL): a potential lead for stroke. J Heterocycl Chem 55:1926-1934

Hakonarson H, Almogurea B, Vazquex LM, Sleiman PMA (2018) Identification of novel loci in asthma and methods of use thereof for the diagnosis and treatment of asthma. PCT Int Appl WO 2018018004 A1 20180125

Hamidpour R, Hamidpour S, Hamidpour M, Sohraby M, Hamidpour M (2015) Turmeric (Curcuma longa): from a variety of traditional medicinal application to its novel roles as active antioxidant, anti-inflammatory, anti-cancer, and anti-diabetes. Int J Pharmacol Phytochem Ethnomed $1: 37-45$

Hammond ML, Heck JV, Zambias RA (1992) Cyclic hexapeptides having antibiotic activity. Eur Pat Appl EP 500170 A2 19920826

Harvey AL, Edrada-Ebel R, Quinn RJ (2015) The re-emergence of natural products for drug discovery in the genomics era. Nat Rev Drug Discov $14: 111$

Hatamoto M, Aizawa R, Fukuchi T (2016) Fungicide composition for agriculture and horticulture. Jpn Kokai Tokkyo Koho JP 2016199526 A 20161201

Hermes DJ, Xu C, Poklis JL, Niphakis MJ, Cravatt BF, Mackie K, Lichtman AH, Ignatowska-Jankowska BM, Fitting S (2018) Neuroprotective effects of fatty acid amide hydrolase catabolic enzyme inhibition in a HIV-1 Tat model of neuroAIDS. Neuropharmacology 141:55-65

Hirata H, Okawara B, Ono K, Akane M (2018) The therapeutic agent for lymphoedema comprising $\beta 2$ simulant. Jpn Kokai Tokkyo Koho JP 2018108969 A 20180712

Hyun TK, Eom SH, Kim JS (2014) Molecular docking studies for discovery of plant-derived a-glucosidase inhibitors. Plant Omics 7:166

Ichihashi S, Okamura D (2017) Useful biocontrol composition having excellent pesticidal activity and biocontrol method using the same. Jpn. Kokai Tokkyo Koho JP 2017001958 A 20170105

Ihori Y, Watanabe S, Inoue Shuuji, Kang CK, Shiinoki Y (2018) Preparation of guanidine compounds as agrochemical fungicides. PCT Int AppI WO 2018097126 A1 20180531

Jarrott B, Williams SJ (2016) Chronic brain inflammation: the neurochemical basis for drugs to reduce inflammation. Neurochem Res 41:523-533

Jia Z, Zhu H, Li Y, Misra HP (2009) Cruciferous nutraceutical 3H-1,2-dithiole3-thione protects human primary astrocytes against neurocytotoxicity elicited by MPTP, MPP +, 6-OHDA, HNE and acrolein. Neurochem Res 34:1924-1934

Johnson MR (2015) Chemically and metabolically stable dipeptide possessing potent sodium channel blocker activity. U.S. Patent 9,072,738

Jung EB, Trinh TA, Lee TK, Yamabe N, Kang KS, Song JH, Choi S, Lee S, Jang TS, Kim KH, Hwang GS (2018) Curcuzedoalide contributes to the cytotoxicity of Curcuma zedoaria rhizomes against human gastric cancer AGS cells through induction of apoptosis. J Ethnopharmacol 213:48-55

Just R, Demmer O, Giehm L, Villadsen JS, Munch HK, Skarbaliene J, Deryabina MA, Hamprecht DW, Mathiesen JM (2016) Amylin analogues and use thereof in treatment of disorders including obesity, excess food intake and associated metabolic diseases such as diabetes. PCT Int Appl WO 2016146739 A1 20160922

Kacem N, Roumy V, Duhal N, Merouane F, Neut C, Christen P, Hostettmann K, Rhouati S (2016) Chemical composition of the essential oil from Algerian Genista quadriflora Munby and determination of its antibacterial and antifungal activities. Ind Crops Prod 90:87-93

Kaneria MJ, Rakholiya KD, Marsonia LR, Dave RA, Golakiya BA (2018) Nontargeted metabolomics approach to determine metabolites profile and antioxidant study of Tropical Almond (Terminalia catappa L.) fruit peels using GC-QTOF-MS and LC-QTOF-MS. J Pharm Biomed Anal $160: 415-427$

Keglevich G (2015) Application of microwave irradiation in the synthesis of P-heterocycles. Green synthetic approaches for biologically relevant heterocycles. Elsevier, Amsterdam, pp 559-570

Khan NA, Siddiqui R (2009) Acanthamoeba affects the integrity of human brain microvascular endothelial cells and degrades the tight junction proteins. Int J Parasitol 39:1611-1616

Khan NA, Osman K, Goldsworthy GJ (2008) Lysates of Locusta migratoria brain exhibit potent broad-spectrum antibacterial activity. J Antimicrob Chemother 62:634-635

Kharkwala GC, Pandea C, Tewari G, Panwarb A, Pandeb V (2017) Terpenoid composition and antimicrobial activity of essential oil from Torilis japonica (Houtt.) DC. J Indian Chem Soc 94:191-194

Kim SG, Ki SH, Hwang SH (2016) Pharmaceutical composition containing 1,2-dithiolthione derivative for preventing or treating disease caused by overexpression of LXR-a. U.S. Patent 9,370,504

Klein LL, Li L, Chen HJ, Curty CB, DeGoey DA, Grampovnik DJ, Leone CL, Thomas SA, Yeung CM, Funk KW, Kishore V (2000) Total synthesis and antifungal evaluation of cyclic aminohexapeptides. Bioorg Med Chem 8:1677-1696

Komorowska-kulik J, Ptaszkowska J, Turos-biernacka M, Koperska M, Laszcz E Zielinski J (1998) Fungicidal agent. Pol PL 175313 B1 19981231

Koo JH, Lee WH, Lee CG, Kim SG (2012) Fyn inhibition by cycloalkane-fused 1,2-dithiole-3-thiones enhances antioxidant capacity and protects mitochondria from oxidative injury. Mol Pharmacol 82:27-36

Ksouri A, Dob T, Belkebir A, Dahmane D, Nouasri A (2017) Volatile compounds and biological activities of aerial parts of Pituranthos scoparius (Coss and Dur) Schinz (Apiaceae) from Hoggar, southern Algeria. Trop J Pharm Res 16:51-58

Kuo PC, Brown DA, Scofield BA, Yu IC, Chang FL, Wang PY, Yen JH (2016) 3H-1, 2-dithiole-3-thione as a novel therapeutic agent for the treatment of experimental autoimmune encephalomyelitis. Brain Behav Immun 57:173-186

Kuo PC, Yu IC, Scofield BA, Brown DA, Curfman ET, Paraiso HC, Chang FL, Yen $\mathrm{JH}$ (2017) 3H-1,2-Dithiole-3-thione as a novel therapeutic agent for the treatment of ischemic stroke through Nrf2 defense pathway. Brain Behav Immun 62:180-192

Kwak MK, Itoh K, Yamamoto M, Sutter TR, Kensler TW (2001) Role of transcription factor Nrf2 in the induction of hepatic phase 2 and antioxidative enzymes in vivo by the cancer chemoprotective agent, $3 \mathrm{H}$-1,2-dimethiole-3-thione. Mol Med 7:135

Lee S, Duce I, Atkins H, Khan NA (2011) Cockroaches and locusts: physicians' answer to infectious diseases. Int J Antimicrob Agents 37:279

Lee GJ, Kim YH, Kim HJ, Lee HY, Jung SW, Jung JE, Seo EG (2013) Preparation of UCH-L1 inhibitor. Repub Korean Kongkae Taeho Kongbo KR 2013112519 A 20131014

Lee KJ, Kim Y, Kim HJ, Lee HY, Joung S, J JE, Seo EK (2014) Preparation of benzene derivatives as UCH-L1 inhibitors. PCT Int Appl WO 2014185561 A1 20141120

Lee IS, Uh I, Kim KS, Kim KH, Park J, Kim Y, Jung JH, Jung HJ, Jang HJ (2016) Antiinflammatory effects of ginsenoside Rg3 via NF-kB pathway in A549 cells and human asthmatic lung tissue. J Immunol Res 2016:1-11

Lee JH, Kim IW, Kim MA, Ahn MY, Yun EY, Hwang JS (2017) Antimicrobial activity of the scolopendrasin $\vee$ peptide identified from the centipede Scolopendra subspinipes mutilans. J Microbiol Biotechnol 27:43-48

Lee TK, Trinh TA, Lee SR, Kim S, So HM, Moon E, Hwang GS, Kang KS, Kim JH, Yamabe N, Kim KH (2019) Bioactivity-based analysis and chemical characterization of anti-inflammatory compounds from Curcuma zedoaria rhizomes using LPS-stimulated RAW264.7 cells. Bioorg Chem 82:26-32

Lei W, Ni J, Xia X, Jiang M, Bai G (2018) Searching for synergistic calcium antagonists and novel therapeutic regimens for coronary heart disease 
therapy from a Traditional Chinese Medicine, Suxiao Jiuxin Pill. J Chromatogr B 1092:220-227

Li S, Shi H, Chang W, Li Y, Zhang M, Qiao Y, Lou H (2017) Eudesmane sesquiterpenes from Chinese liverwort are substrates of Cdrs and display antifungal activity by targeting Erg6 and Erg11 of Candida albicans. Bioorg Med Chem 25:5764-5771

Lim HS, Yo SR, Lee MY, Seo CS, Shin HK, Jeong SJ (2018) Potential inhibitory effects of the traditional herbal prescription Hyangso-san against skin inflammation via inhibition of chemokine production and inactivation of STAT1 in HaCaT keratinocytes. Mol Med Rep 17:2515-2522

Liu X, Cao A, Ouyang C, Li Y, Yan D, Wang Q, Guo M (2015) Fungicide containing Eupatorium adenophora extract and mancozeb. Faming Zhuanli Shenqing CN 105123721 A 20151209

Liu X, Cao A, Ouyang C, Li Y, Yan D, Wang Q, Guo M (2016) A compound fungicide containing Ageratina adenophora extract and iprodione. Faming Zhuanli Shenqing CN 105532707 A 20160504

Lu-Si L, Cheng P, Qin-Mei Z, Xiong L, Guo L, Wang YN, Dai O (2017) Effects of Angelica oil and the isolated butylphthalides on glutamate-induced neurotoxicity in PC12 cells. Rec Nat Prod 11:217

Macegoniuk K, Kowalczyk R, Rudzińska A, Psurski M, Wietrzyk J, Berlicki Ł (2017) Potent covalent inhibitors of bacterial urease identified by activityreactivity profiling. Bioorg Med Chem Lett 27:1346-1350

Maiwald A, Hammami M, Wagner S, Heine A, Klebe G, Steinmetzer T (2016) Changing the selectivity profile-from substrate analog inhibitors of thrombin and factor Xa to potent matriptase inhibitors. J Enzyme Inhib Med Chem 31:89-97

Martin A (2018) Compositions and methods for the treatment and prevention of chronic hypoxemia and dyspnea. U.S. Patent Application 15/441,552

Matsunaga S, Myamae Y, Mukoyama K (1996) Bleaching detergent compositions showing good perfume fragrance retention. Jpn Kokai Tokkyo Koho JP 08218094 A 19960827

Maya SP, Beltrán DD, Lemercier P, Leiva-Salinas C (2014) Necrotizing fasciitis: an urgent diagnosis. Skeletal Radiol 43:577-589

Mehner C, Müller D, Krick A, Kehraus S, Löser R, Gütschow M, Maier A, Fiebig HH, Brun R, König GM (2008) A novel $\beta$-amino acid in cytotoxic peptides from the cyanobacterium Tychonema sp. Eur J Org Chem 2008:1732-1739

Mérillon JM, Rivière C (2018) Natural antimicrobial agents, vol 19. Springer, Berlin, pp 1-342

Migahed MA, El-kousy SM, Tayel RF, Zaki EG (2017) Synthesis, characterization, surface active properties, biological activity of ethoxylated dodecyl benzenesulfonamide. J Pharm Biol Chem Sci 8:1967

Mitchard M (1988) Sulphur compounds used in medicine, vol 6, pp 183-202

Mo EJ, Yang HJ, Jeong JY, Kim SB, Liu Q, Hwang BY, Lee MK (2016) Pancreatic lipase inhibitory phthalide derivatives from the rhizome of Cnidium officinale. Rec Nat Prod 10:148

Mohamede ASI, Elneairy MAA, Eldine SM (2015) 2,4-Cycloaddition reactions: preparation and cytotoxicity of novel quinoline and pyrrolo $[3,4-f]$ quinoline derivatives. Int J Pharm Pharm Sci 7:64-68

Moon SS, Cho N, Shin J, Seo Y, Lee CO, Choi SU (1996) Jineol, a cytotoxic alkaloid from the centipede Scolopendra subspinipes. J Nat Prod 59:777-779

Nawamaki K, Kuroyanagi M (1996) Sesquiterpenoids from Acorus calamus as germination inhibitors. Phytochemistry 43:1175-1182

Negi PS, Jayaprakasha GK, Jagan Mohan Rao L, Sakariah KK (1999) Antibacterial activity of turmeric oil: a byproduct from curcumin manufacture. J Agric Food Chem 47:4297-4300

Newton GGF, Abraham EP (1955) Cephalosporin C, a new antibiotic containing sulphur and D-a-aminoadipic acid. Nature 175:548

Nigam Y, Dudley E, Bexfield A, Bond AE, Evans J, James J (2010) The physiology of wound healing by the medicinal maggot, Lucilia sericata. Adv In Insect Phys 39:39-81

Niu Y, Wang M, Cao Y, Nimmagadda A, Hu J, Wu Y, Cai J, Ye XS (2018) Rational design of dimeric lysine $\mathrm{N}$-alkylamides as potent and broad-spectrum antibacterial agents. J Med Chem 61:2865-2874

Nomura A, Kachi H, Matsuzawa M, Tokura H, Komori M (2016) Water-based cosmetic containing agar, xanthan gum and water-soluble polymer. PCT Int Appl WO 2016143663 A1 20160915

Ooi CC, Good NM, Williams DB, Lewanowitsch T, Cosgrove LJ, Lockett TJ, Head RJ (2010) Efficacy of butyrate analogues in HT-29 cancer cells. Clin Exp Pharmacol Physiol 37:482-489
Or YS (1997) Preparation of tricyclic erythromycins as bactericides. WO 9717356

Pagano E, Borrelli F, Orlando P, Romano B, Monti M, Morbidelli L, Aviello G, Imperatore R, Capasso R, Piscitelli F, Buono L (2017) Pharmacological inhibition of MAGL attenuates experimental colon carcinogenesis. Pharmacol Res 119:227-236

Pandey P, Chaurasiya ND, Tekwani BL, Doerksen RJ (2018) Interactions of endocannabinoid virodhamine and related analogs with human monoamine oxidase-A and-B. Biochem Pharmacol 155:82-91

Park SC, Park JU, Yoo CY, Oh SY, Lee ED, Park JH, Park CU (2018) A composition for controlling nematodes containing an alkylamine and a fatty acid. Repub Korea KR 1827442 B1 20180208

Pascal RA Jr, Oliver MA, Chen YJ (1985) Alternate substrates and inhibitors of bacterial 4-hydroxyphenylpyruvate dioxygenase. Biochemistry 24:3158-3165

Pelcman B, Bengtsson T (2018) Combinations of adrenergic receptor agonists for the treatment of type 2 diabetes. PCT Int Appl WO 2018011588 A1 20180118

Peng K, Kong Y, Zhai L, Wu X, Jia P, Liu J, Yu H (2010) Two novel antimicrobial peptides from centipede venoms. Toxicon 55:274-279

Perez-Leal O, Barrero CA, Merali S (2017) Pharmacological stimulation of nuclear factor (erythroid-derived 2)-like 2 translation activates antioxidant responses. J Biol Chem 292:14108-14121

Petrov AD, Nikishin GI, Nevolin FV, Kral-Osikina GA, Orekhova MV, Yushkevich AV (1958) Dependence of surface-active and detergent properties of alkylbenzenesulfonates on the length and structure of the alkyl chain. Masloboino-Zhirovaya Promyshlennost 24:23-29

Preston D, Murphy RB (2015) Antiviral epicatechins, epicatechin oligomers, or thiolated epicatechins from theobroma cacao for treatment of genital warts. U.S. Patent Application 14/202,103

Rock EM, Moreno-Sanz G, Limebeer CL, Petrie GN, Angelini R, Piomelli D, Parker LA (2017) Suppression of acute and anticipatory nausea by peripherally restricted fatty acid amide hydrolase inhibitor in animal models: role of PPARa and CB1 receptors. Br J Pharmacol 174:3837-3847

Rojewska M, Biadasz A, Kotkowiak M, Olejnik A, Rychlik J, Dudkowiak A, Prochaska K (2013) Adsorption properties of biologically active derivatives of quaternary ammonium surfactants and their mixtures at aqueous/air interface. I. Equilibrium surface tension, surfactant aggregation and wettability. Colloids Surf B Biointerfaces 110:387-394

Sato M (2016) Aerosol type deodorant composition containing hydrophilic powder and dicarboxylate-based deodorant. Jpn Kokai Tokkyo Koho JP 2016000719 A 20160107

Savage Paul B (2017) Preparation of cationic steroidal antimicrobials for treating bacterial infections. Pat Appl Publ US 20170210776 A1 20170727

Scherzer C (2018) Combinations including beta-adrenoreceptor agonists for treatment of Parkinson's disease and movement disorders. PCT Int Appl WO 2018195473 A1 20181025

Science daily (2011) World population to surpass 7 billion in 2011; explosive population growth means challenges for developing nations https:// www.sciencedaily.com/releases/2011/07/110728144933.htm. Accessed 10 June 2019

Smith T (2000) Antibiotics from soil bacteria. Nat Struct Mol Biol 7:189-190

Sofian FF, Tamba L, Susilawati Y, Runadi D, Tjitraresmi A, Ramadhania ZM, Wardojo MM (2017) Larvicidal activity of Curcuma heyneana Val. \& v. Zijp rhizome against Aedes aegypti larvae. Res J Pharm Biol Chem Sci 8:80-88

Srivastava SK, Babu N, Pandey H (2009) Traditional insect bioprospecting —as human food and medicine

Stewart GR, Maher C, Gay B, Andresen JM, Fox M, Goldstein D, Petrou S, Petrovski S (2018) Methods of treating epilepsy and voltage-gated potassium channels KCNQ2 related conditions. PCT Int Appl WO 2018204765 A1 20181108

Stojakowska A, Galanty A, Malarz J, Michalik M (2019) Major terpenoids from Telekia speciosa flowers and their cytotoxic activity in vitro. Nat Prod Res 33:1804-1808

Stürzebecher J, Steinmetzer T, Schweinitz A, Stürzebecher A, Dönnecke D (2015) Base-substituted benzylamine analogs for use as coagulation factor Xa inhibitors, the production and use thereof. U.S. Patent $9,090,658$ 
Surolia A, Gautam RK, Dwivedi VK, Gupta S (2014) Synthetic peptides and random copolymers for the treatment of autoimmune disorders. U.S. Pat Appl Publ US 20140348861 A1 20141127

Tacconelli E, Carrara E, Savoldi A, Harbarth S, Mendelson M, Monnet DL, Pulcini C, Kahlmeter G, Kluytmans J, Carmeli Y, Ouellette M (2018) Discovery, research, and development of new antibiotics: the WHO priority list of antibiotic-resistant bacteria and tuberculosis. Lancet Infect Dis 18:318-327

Tanwar B, Kumar A, Yogeeswari P, Sriram D, Chakraborti AK (2016) Design, development of new synthetic methodology, and biological evaluation of substituted quinolines as new anti-tubercular leads. Bioorg Med Chem Lett 26:5960-5966

Toguri JT, Leishman E, Szczesniak AM, Laprairie RB, Oehler O, Straiker AJ, Kelly MEM, Bradshaw HB (2018) Inflammation and CB2 signaling drive novel changes in the ocular lipidome and regulate immune cell activity in the eye. Prostaglandins Other Lipid Mediat 139:54-62

Tran QT, Xu L, Phan V, Goodwin SB, Rahman M, Jin VX, Sutter CH, Roebuck BD, Kensler TW, George EO, Sutter TR (2009) Chemical genomics of cancer chemopreventive dithiolethiones. Carcinogenesis 30:480-486

Tran HNK, Cao TQ, Kim JA, Youn UJ, Kim S, Woo MH, Min BS (2018) Anti-inflammatory activity of compounds from the rhizome of Cnidium officinale. Arch Pharm Res 41:977-985

Undheim EA, King GF (2011) On the venom system of centipedes (Chilopoda), a neglected group of venomous animals. Toxicon 57:512-524

Vosátka R, Krátký M, Švarcová M, Janoušek J, Stolaříková J, Madacki J, Huszár S, Mikušová K, Korduláková J, Trejtnar F, Vinšová J (2018) New lipophilic isoniazid derivatives and their 1,3,4-oxadiazole analogues: synthesis, antimycobacterial activity and investigation of their mechanism of action. Eur J Med Chem 151:824-835

Wagman GH (1980) Antibiotics from Micromonospora. Annu Rev Microbiol 34:537-558

Wang CC, Chen WR (2017) Method for preventing cancer by using phthalides. U.S. Patent Application 15/071,190

Wang C, Li J, Yang R, Zhao Y, Cheng Y, Zhang Z, He L (2014) Petasins from the rhizomes of Ligularia fischeri and its derivatives. Rec Nat Prod 8:156

Wang L, Wang M, Hu J, Shen W, Hu J, Yao Y, Wang X, Afzal CM, Ma R, Li G (2017a) Protective effect of 3H-1, 2-dithiole-3-thione on cellular model of Alzheimer's disease involves Nrf2/ARE signaling pathway. Eur J Pharmacol 795:115-123

Wang N, Zhang Q, Xin H, Shou D, Qin L (2017b) Osteoblast cell membrane chromatography coupled with liquid chromatography and time-offlight mass spectrometry for screening specific active components from traditional Chinese medicines. J Sep Sci 40:4311-4319

Wang J, Wu J, Li X, Liu H, Qin J, Bai Z, Chi B, Chen X (2018a) Identification and validation nucleolin as a target of curcumol in nasopharyngeal carcinoma cells. J Proteomics 182:1-11

Wang JJ, Yakatan GJ, Lin TN, Gao JH (2018b) Pharmaceutical compositions and methods of treating cardiovascular diseases. U.S. Patent Application $15 / 973,132$

Wang MM, Chu WC, Yang Y, Yang QQ, Qin SS, Zhang E (2018c) Dithiocarbamates: efficient metallo- $\beta$-lactamase inhibitors with good antibacterial activity when combined with meropenem. Bioorg Med Chem Lett 28:3436-3440

Weinstein E, Mata-Fink J, Kahvejian A, Afeyan NB, Jeanbart LK, Lantermann A, Hurov JB (2018) Neuromodulating compositions and related therapeutic methods for the treatment of cancer. PCT Int Appl WO 2018022668 A2 20180201

Wenhua R, Shuangquan Z, Daxiang S, Kaiya Z, Guang Y (2006) Induction, purification and characterization of an antibacterial peptide scolopendrin I from the venom of centipede Scolopendra subspinipes mutilans. Indian J Biochem Biophys 43:88-93
Wisetsai A, Lekphrom R, Schevenels FT (2018) A novel cyclohexenone from Trachyspermum roxburghianum. Nat Prod Res 32:2499-2504

Wortley MA, Adcock JJ, Dubuis ED, Maher SA, Bonvini SJ, Delescluse I, Kinloch R, McMurray G, Perros-Huguet C, Papakosta M, Birrell MA (2017) Targeting fatty acid amide hydrolase as a therapeutic strategy for antitussive therapy. Eur Respir J 50:1700782

Wrasidlo W, Natala SR (2018) Lipid-substituted amino 1,2-and 1,3-diol compounds as modulators of TLR2 dimerization. PCT Int Appl WO 2018026866 A1 20180208

Wu P, Liu S, Su J, Chen J, Li L, Zhang R, Chen T (2017) Apoptosis triggered by isoquercitrin in bladder cancer cells by activating the AMPK-activated protein kinase pathway. Food Funct 8:3707-3722

Xu J, Zeng GZ, Liu YM, Chen KL, Sun ZH, Zhang YM, Tan NH (2014) Sesquiterpenoids and diterpenes from Chamaecyparis obtusa var. breviramea $\mathrm{f}$ crippsii. Zeitschrift für Naturforschung B 69:362-368

Xu J, Zhu HL, Zhang J, Du T, Guo EY, Liu WY, Luo JG, Ye F, Feng F, Qu W (2018) Sesquiterpenoids from Chloranthus anhuiensis with neuroprotective effects in PC12 cells. J Nat Prod 81:1391-1398

Zambias RA, Hammond ML, Heck JV, Bartizal K, Trainor C, Abruzzo G, Schmatz DM, Nollstadt KM (1992) Preparation and structure-activity relationships of simplified analogs of the antifungal agent cilofungin: a total synthesis approach. J Med Chem 35:2843-2855

Zhang F, Qi P, Xue R, Li Z, Zhu K, Wan P, Huang C (2015) Qualitative and quantitative analysis of the major constituents in Acorus tatarinowii Schott by HPLC/ESI-QTOF-MS/MS. Biomed Chromatogr 29:890-901

Zhang C, Xie L, Guan F, Cui Y (2018a) 3H-1, 2-dithiole-3-thione protects PC12 cells against amyloid beta 1-42 (A $1-42)$ induced apoptosis via activation of the ERK1/2 pathway. Life Sci 213:74-81

Zhang YQ, Guo QY, Li QY, Ren WQ, Tang SH, Wang SS, Liang RX, Li DF, Zhang Y, Xu HY, Yang HJ (2018b) Main active constituent identification in Guanxinjing capsule, a traditional Chinese medicine, for the treatment of coronary heart disease complicated with depression. Acta Pharmacol $\operatorname{Sin} 39: 975$

Zhao RY, Yang Q, Huang Y, Gai S, Zhao L, Ye H, Guo H, Tong Q, Cao M, Jia J, Yang C, Li W, Zhou X, Xie H, Lin C, Guo Z, Ye Z (2016) Preparation of specific conjugation bridge linkers and immunoconjugates and methods of using them. PCT Int Appl WO 2016059622 A2 20160421

Zhao RY, Yang Q, Huang Y, Gai S, Ye H, Yang C, Guo H, Zhou X, Xie H, Tong Q, Minjun C, Linyao Z, Junxiang J, Wenjun L, Xiaotao Z, Chen L, Yifang $X$, Zixiang G (2017) Preparation of derivatives of amanita toxins and their conjugation to a cell binding molecule as targeted therapeutic agents. PCT Int Appl WO 2017046658 A1 20170323

Zhao YR, Yang Q, Huang Y, Gai S, Ye H, Zhao L, Yang C, Guo H, Zhou X, Xie H, Zhu H, Xu Y, Tong Q, Jia J, Cao M, Li W, Gao S, Guo Z, Bai L, Li C, Yang Y, Wang C, Ye Z (2018) Conjugation linkers, cell binding molecule-drug conjugates containing the peptide linkers, methods of making and uses such conjugates with the linkers. PCT Int AppI WO 2018086139 A1 20180517

Zubrzycki M, Janecka A, Liebold A, Ziegler M, Zubrzycka M (2017) Effects of centrally administered endocannabinoids and opioids on orofacial pain perception in rats. Br J Pharmacol 174:3780-3789

\section{Publisher's Note}

Springer Nature remains neutral with regard to jurisdictional claims in published maps and institutional affiliations. 